University of Montana

ScholarWorks at University of Montana

Spring 2016

\title{
The Federalist Safeguards of Politics
}

Anthony Johnstone

Alexander Blewett III School of Law at the University of Montana, anthony.johnstone@umontana.edu

Follow this and additional works at: https://scholarworks.umt.edu/faculty_lawreviews

Part of the Constitutional Law Commons

Let us know how access to this document benefits you.

\section{Recommended Citation}

Johnstone, Anthony, "The Federalist Safeguards of Politics" (2016). Faculty Law Review Articles. 133.

https://scholarworks.umt.edu/faculty_lawreviews/133

This Article is brought to you for free and open access by the Faculty Publications at ScholarWorks at University of Montana. It has been accepted for inclusion in Faculty Law Review Articles by an authorized administrator of ScholarWorks at University of Montana. For more information, please contact scholarworks@mso.umt.edu. 


\title{
The Federalist SAfeguards of Politics
}

\author{
ANTHONY JOHNSTONE*
}

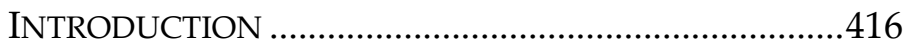

I. REPUBLICANISM, PERFECTIONISM, AND

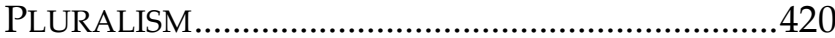

A. Republican Pluralism...................................422

B. Republican Perfectionism.............................427

II. The NAtionalization OF State Politics.......433

A. Congressional Nationalization ....................435

B. Executive Nationalization ............................437

C. Judicial Nationalization ................................437

III. THE DisTINCTIVENESS OF STATE

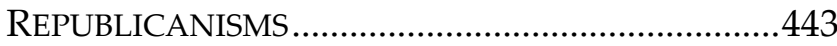

A. Legal Distinctions ..........................................445

1. Election Administration.........................446

2. Constituencies and Districting..............448

3. Parties .......................................................450

4. Campaign Finance .................................453

5. Other Factors ..........................................456

B. Rules, Regimes, and Systems of

Republicanism

C. The Persistence of State Political Cultures.460

1. Participation and Voting Turnout ........461

2. Equality and Campaign Finance ..........463

3. Competition and Contested Races .......465

4. Representation and Policy Alignment.466

IV. THE FEDERALIST SAFEGUARDS OF POLITICS.........467

A. State Means ..................................................472

B. Republican Ends..........................................478

1. Competition ............................................480

2. Equality ...............................................481

\footnotetext{
* Associate Professor, Alexander Blewett III School of Law, University of Montana. The Author thanks Yasmin Dawood, Richard Hasen, William Marshall, Richard Pildes, and participants at the American Political Science Association panel on Political Parties and Campaign Finance in the Post-Citizens United World for comments; Zachary Rogala, Anne Sherwood, and Constance Van Kley for editorial and research assistance; and his family for their support. The Author served as counsel for the State of Montana in Citizens United v. Federal Election Commission as amicus curiae and in American Tradition Partnership v. Bullock.
} 
3. Representation.......................................482

4. Participation

\section{INTRODUCTION}

"The United States shall guarantee to every State in this Union a Republican Form of Government...."1 These words expound the fundamental federal constitutional safeguard of representative democracy in American states. Conventional wisdom portrays this safeguard for a "Republican Form of Government" as irrelevant to contemporary constitutional law and politics because the Supreme Court-and Congress, for that matter-will not enforce the Guarantee Clause. ${ }^{2}$ Yet the real problem with the Guarantee Clause is not that the United States enforces it too little, but that it enforces it too much. The Clause's political theoretical contents have spilled into other enforceable constitutional guarantees. There is no shortage of theories proffered to perfect various conceptions of republicanism with the continuing expectation of federal, usually judicial, enforcement. ${ }^{3}$ The Supreme Court, and to a lesser extent the national political branches, have taken the law of democracy beyond the basic rights of political equality expressed elsewhere in the Constitution into the deeply contested realm of republican theory: accountability and participation, majority rule and minority representation, deliberation and responsiveness, equality and liberty of influence, legitimacy and self-expression, and competition and stability. The interaction of these competing perfectionist conceptions of republicanism has led to the incoherence of the constitutional law of politics in the States. Federal efforts have produced a system in which the States, the Union, and the Republican Form of Government would be better served by letting states do more, and the United States less, to fulfill the guarantee.

There is an alternative pluralist conception of the republican guarantee. The Supreme Court once conceded, even while it opened the door to the one-person one-vote principle, "the lack

1. U.S. CONST. art. IV, $\S 4$.

2. See, e.g., Erwin Chemerinsky, Cases under the Guarantee Clause Should be Justiciable, 65 U. COLO. L. REV. 849, 849, 876 (1994).

3. See generally id. 
of criteria by which a court could determine which form of government was republican." ${ }^{4}$ Despite this concession, however, questions about the Republican Form of Government pervade federal supervision of state election law by the Court and its coordinate branches. The Court's subsequent interpretation of the First and Fourteenth Amendments, and of our federalism, masked underlying debates about distinct conceptions of republicanism. Meanwhile the People, through the Constitution itself, refined the republican guarantee by extending the right to vote to all races, ${ }^{5}$ women, ${ }^{6}$ the poor ${ }^{7}$ young adults, ${ }^{8}$ and the People directly in electing their Senators. ${ }^{9}$ Congress further extended the guarantee through legislation enforcing these amendments, thereby enabling the President to implement the guarantee in the States. ${ }^{10}$ The Guarantee Clause itself, and with it any distinction between the States and the Union in the constitutional regulation of politics, faded from view.

The submergence of the broad republican guarantee by these narrower constitutional commitments helped the federal government improve the forms of government in the States. For a time, a federal consensus on basic political equality took the United States several steps toward a more perfect union. The emergence of primaries eventually engaged more voters in the process of party nominations. State and federal campaign finance regulation brought transparency and some measure of equality to campaigns. In the first few decades after passage of the Voting Rights Act, the Constitution empowered, the Congress enacted, the Executive enforced, and the Court upheld a

4. Baker v. Carr, 369 U.S. 186, 222 (1962); see also Evenwel v. Abbott, No. 14-940 (U.S. Apr. 4, 2016), slip op. at 7 (Thomas, J., concurring in the judgment) ("So far as the Constitution is concerned, there is no single 'correct' way to design a republican government.").

5. U.S. CONST. amend. XV.

6. U.S. CONST. amend. XIX.

7. U.S. CONST. amend. XXIV.

8. U.S. CONST. amend. XXVI.

9. U.S. CONST. amend. XVII; see also U.S. CONST. amend. XXIII, § 1 ("The District constituting the seat of Government of the United States shall appoint in such manner as the Congress may direct: A number of electors of President and Vice President equal to the whole number of Senators and Representatives in Congress to which the District would be entitled if it were a State ....").

10. See, e.g., Voting Rights Act of 1965, Pub. L. No. 89-110, 79 Stat. 445 (codified as amended in scattered sections of 52 U.S.C.). 
powerful right of access to the franchise. ${ }^{11}$ This consensus, however, has long since ended. As the United States nears the substantial fulfillment of basic political equality in the Second Reconstruction, the current political stalemate among the federal legislative, executive, and judicial branches produces a one-size-fits-all republican system that is as dysfunctional as it is dominant.

After the Court in Bush v. Gore brought to light the "common, if heretofore unnoticed, phenomenon" of serious problems in local administration of federal elections, ${ }^{12}$ the President still conceded more than a decade later, "[W]e have to fix that." ${ }^{13}$ In Citizens United, the Court prematurely heralded "[a] campaign finance system that pairs corporate independent expenditures with effective disclosure" after invalidating restrictions on corporate campaign expenditures. ${ }^{14}$ But a gridlocked Federal Election Commission and Congress have repeatedly failed to take executive or legislative action necessary to implement such a system. The Court suggested in Shelby County v. Holder, after invalidating the Voting Rights Act's central enforcement mechanism, that "Congress may draft another formula based on current conditions" to address discriminatory voting practices, ${ }^{15} \mathrm{a}$ suggestion unlikely to be taken up in the foreseeable future. The one recent case in which the Court acknowledged dysfunction in federal election regulation, the inaction of the understaffed Election Assistance Commission in Arizona v. Inter Tribal Council, ${ }^{16}$ laid bare fundamental yet vague divisions among the Justices about the scope of the federal government's power to structure elections in the states. ${ }^{17}$ Even the Guarantee Clause itself resur-

11. See, e.g., Katzenbach v. Morgan, 384 U.S. 641 (1966).

12. 531 U.S. 98,103 (2000).

13. See Brad Plumer, 'We have to fix that,' but will we?, WASH. POST (Nov. 8, 2012), https://www.washingtonpost.com/politics/decision2012/we-have-to-fix-that-butwill-we/2012/11/08/c83b4976-29ca-11e2-bab2-eda299503684_story.html

[http://perma.cc/7WCN-X5RB].

14. Citizens United v. Fed. Election Comm'n, 558 U.S. 310, 370 (2010).

15. 133 S. Ct. 2612, 2631 (2013).

16. See 133 S. Ct. 2247, 2260 (2013); see also id. at 2273 (Alito, J., dissenting) ("The EAC currently has no members, and there is no reason to believe that it will be restored to life in the near future.").

17. See id. at 2253 ("The [Elections] Clause's substantive scope is broad."); id. at 2261 (Kennedy, J., concurring in part) ("[I]n all events the State's undoubted interest in the regulation and conduct of elections must be taken into account and 
faced in a challenge to a Colorado tax limit initiative. ${ }^{18}$ The Court's decision in Arizona State Legislature v. Arizona Independent Redistricting Commission undermined the plaintiffs' standing in the Colorado case, but not before dropping a provocative footnote that "[p]erhaps not all claims under the Guarantee Clause present nonjusticiable political questions." 19

This Article argues that states do and should play as important a role as the federal government in articulating and implementing the law governing state political processes, or in formal terms, their republican forms of government. ${ }^{20}$ The argument has four parts. Part I introduces the basic meaning of the guarantee and its amendment. Beyond a consensus that holds our republicanism to require basic political equality, various perfectionist conceptions of a republican form of government diverge, giving way to the essential pluralism of republican governments in a federal system. Part II explains how the Supreme Court, Congress, and the Executive are now unable to articulate, let alone implement, a workable national consensus on any perfectionist republicanism beyond a thin conception of those basic rights to political equality. Part III describes the

ought not to be deemed by this Court to be a subject of secondary importance."); id. at 2268 (Thomas, J., dissenting) ("It is, thus, difficult to maintain that the Times, Places and Manner Clause gives Congress power beyond regulating the casting of ballots and related activities ...."); id. at 2271 (Alito, J., dissenting) ("The Court has it exactly backwards when it declines to apply the presumption against preemption because 'the federalism concerns underlying the presumption in the Supremacy Clause context are somewhat weaker' in an Elections Clause case like this one.").

18. Kerr v. Hickenlooper, 744 F.3d 1156, 1181 (10th Cir. 2014) (holding Guarantee Clause claims arising from state tax limit initiative are justiciable notwithstanding the political question doctrine), vacated and remanded, 135 S. Ct. 2927 (2015).

19. 135 S. Ct. 2652, 2660 n.3 (quoting New York v. United States, 505 U.S. 144, $185(1992))$.

20. The title of this Article plays on Herbert Wechsler's famous The Political Safeguards of Federalism: The Role of the States in the Composition and Selection of the National Government, 54 COLUM. L. REV. 543 (1954). Wechsler's thesis was "that the existence of the states as governmental entities and as the sources of the standing law is in itself the prime determinant of our working federalism," so that the national political process protects federalism in the states. Id. at 546. This Article inverts Wechsler's claim, arguing that the existence of the States as the (primary) sources of the standing law (of the political process) is itself the prime determinant of our working (or non-working) political process, so that state political processes protect the national political process. 
states as the source of persistent pluralism in their republican forms of government, as both legal systems and political cultures that produce and are sustained by those systems. Part IV argues that these distinctions in how states articulate and implement their own plural versions of republicanism are crucial to efforts toward reforming, let alone perfecting, republicanism at the national level. Given the unsettled visions of republicanism at the national level and the structural autonomy the states must retain at the core of our federal system, a plurality of views on republicanism among the states is not only durable but desirable.

\section{REPUBLICANISM, PLURALISM, AND PERFECTIONISM}

In defending the Constitution as "strictly republican," James Madison argued that it established a composition of both a "federal form [of government], which regards the Union as a Confederacy of sovereign states[,]" and "a national government, which regards the Union as a consolidation of the States." ${ }^{21}$ We might recognize the same distinction in the Constitution's guarantee of republicanism in the States. The Guarantee Clause itself, alongside other direct constitutional guarantees of basic political equality such as the extension of voting rights, contains both federal and national modes of implementing republicanism.

The federal mode establishes the necessary terms for participating in the confederation, such as the Guarantee Clause's prohibition of state aristocracies that corrupt neighboring states, or the Fifteenth Amendment's prohibition on race-based discrimination in voting that undermines the reconstructed Union. ${ }^{22}$ These provisions also contain important nationalizing elements in terms of setting a floor of basic political equality among individual citizens (no monarchs) and between classes of citizens (no abridgement of the vote because of race) within the States. Such rules unify the nation under a certain broad conception of republicanism even as they preserve the confederation of autonomous States. For example, in addition to the Guarantee Clause, the Constitution empowers the States to

21. THE FEDERALIST No. 39, at 280, 282 (James Madison) (Benjamin F. Wright ed., 1961).

22. See U.S. CONST. amend. XV. 
prescribe the time, place, and manner of federal elections subject to congressional alteration. ${ }^{23}$ Such provisions serve as the Union's shield to protect the federal republic against dangerous or uncooperative non-republican state governments. Primarily, the Constitution directly governs state political structures as a federal check against state departures from republicanism that might jeopardize the national government. Outside of such threats, the Constitution reserves to the States a sphere of autonomy in formulating republicanism. ${ }^{24}$

This federal conception of the republican guarantee is pluralist. Beyond the consensus of basic political equality, and consistent with the security of the Union, pluralist republicanism allows states to adapt their forms of government to their own circumstances. These distinct republican forms mutually reinforce and are reinforced by distinct political cultures arising in each state. An alternative national conception of the republican guarantee, one that exceeds the scope necessary for basic political equality and the security of the union, might be called perfectionist. Rather than take the guarantee as a shield, perfectionist republicanism takes it as a sword for the Union to attack state conceptions of republicanism that might differ from that of the Union, or those the Union's officers (legislative, executive, and judicial) might think ought to be imposed on the States nationally. It nationalizes state politics by dissolving distinctions between the forms of government at the federal and state levels. ${ }^{25}$ In its most pronounced form, republican perfectionism reads the Guarantee Clause to require the States to con-

23. See U.S. CONST. art. I, $\S 4$, cl. 1.

24. The sphere is autonomous, not sovereign, due to Congress's broad authority to displace state regulation of federal elections under the Elections Clause and prohibit state discrimination in voting under the voting rights amendments. See Franita Tolson, Reinventing Sovereignty?: Federalism as a Constraint on the Voting Rights Act, 65 VAND. L. REV. 1195, 1202 (2012). On differences between sovereignty and autonomy accounts, as well as the cooperative account, see Heather $\mathrm{K}$. Gerken, Our Federalism(s), 53 WM. \& MARY L. REV. 1549, 1552 (2012) (describing "the de jure autonomy associated with the sovereignty account; the de facto autonomy associated with process federalism; and the power of the servant, which is the best way to conceptualize state power in cooperative federal regimes").

25. The Author thanks Richard Pildes for clarifying the point that the argument's concern is nationalization rather than federalization. See generally James A. Gardner, The Myth of State Autonomy: Federalism, Political Parties, and the National Colonization of State Politics, 29 J. L. \& POL. 1 (2013). 
fer positive rights that the Constitution does not require from the federal government.

\section{A. Republican Pluralism}

Republican pluralism recognizes that there is no definitive conception of a "Republican Form of Government." In The Federalist, the guarantee's co-drafter, Madison, described his view of a republic as simply "a government in which the scheme of representation takes place." 26 As Madison later suggests, this is not to distinguish a republic from what is popularly termed a democracy, a distinction that Akhil Amar notes "dissolves etymologically, with the res publica being a rough Latin equivalent of the Greek demos-kratia-rule by the demos, or people." 27 Rather, as the guarantee's neighboring protections "against Invasion" and "against domestic Violence" 28 suggest, one of its purposes is "to defend the system against aristocratic or monarchical innovations," particularly factions that may "possess such a superiority of pecuniary resources, of military talents and experience, or of secret succors from foreign powers." 29 Within this federally enforced safety, the States may continue "the existing republican forms," or "choose to substitute other republican forms" so long as "they shall not exchange republican for anti-republican Constitutions." 30 Outside of the scope of the guarantee, the States would retain electoral autonomy, as "the component parts of the State governments will in no instance be indebted for their appointment to the direct agency of the federal government, and very little, if at all, to the local influence of its members." 31

26. THE FEDERALIST No. 10, at 129, 133 (James Madison) (Benjamin F. Wright ed., 1961).

27. Akhil Reed Amar, The Central Meaning of Republican Government: Popular Sovereignty, Majority Rule, and the Denominator Problem, 65 U. COLO. L. REV. 749, 760 n.47 (1994).

28. U.S. CONST. art. IV, $\S 4$.

29. THE FEDERALIST No. 43, at 311, 313 (James Madison) (Benjamin F. Wright ed., 1961).

30. Id. at 312 .

31. The Federalist No. 45, at 327 (James Madison) (Benjamin F. Wright, ed. 1961). For an important critique of this premise, see David Schleicher, Federalism and State Democracy, 95 TEX. L. REV. (forthcoming 2016) (arguing many state and local elections are "second order," reflecting voter preferences about federal officials instead of the performance of state and local officials on the ballot). 
The Federalist should be read cautiously as the political advocacy it was, particularly when it promises to leave the States and their governments alone while seeking their joinder in the Union. Yet Robert Natelson's thorough study of the original understanding of the Guarantee Clause also concludes that the Constitution provided little more guidance than to say, "With respect to republicanism, choose the form you wish, so long as your governments are controlled by your citizens, have no kings (or, by another clause, no titled nobility), and honor the rule of law." 32 Similarly, Akhil Amar finds in both its framing and its practice, "The central meaning of Republican Government revolved tightly around popular sovereignty, majority rule, and the people's right to alter or abolish." ${ }^{33}$ There is "nearconsensus," observes Jacob Heller, that "republican governments rule (1) by the majority (and not a monarch), (2) through elected representatives, [and] (3) in separate, coequal branches." 34 This much of the Guarantee Clause is clear and even justiciable in those fortunately rare instances where these basic elements might be lacking. ${ }^{35}$

The republicanism of the Guarantee Clause is therefore more practical than theoretical, more structural than rights-based, and focused on a self-sustaining polity, not political perfection-

32. Robert G. Natelson, A Republic, Not a Democracy? Initiative, Referendum, and the Constitution's Guarantee Clause, 80 TEX. L. REV. 807, 856 (2002); see also Michael W. McConnell, The Redistricting Cases: Original Mistakes and Current Consequences, 24 HARV. J. L. \& PUB. POL'Y 103, 114 (2000) ("There are many systems of representation that would satisfy the Republicanism requirement. But at a minimum, the Clause must mean that a majority of the whole body of the people ultimately governs.").

33. Amar, supra note 27, at 786.

34. Jacob M. Heller, Note, Death by a Thousand Cuts: The Guarantee Clause Regulation of State Constitutions, 62 STAN. L. REV. 1711, 1718 (2010).

35. Luther v. Borden, 48 U.S. (7 How.) 1 (1849), the closest case in which an antebellum Supreme Court (that is, one unconcerned about the deep betrayal of republicanism inherent in slavery) might have delivered on the guarantee, is plausibly read to be about "not whether [Rhode Island's pre-revolutionary royal] charter regime was Republican, but whether it was a Government." Amar, supra note 27, at 776. Adam Kurland provides a fascinating account of a potential invocation of the guarantee in President Franklin Roosevelt's consideration of another extreme case, "Huey Long and the 'totalitarian' state of Louisiana," as well as more questionable cases of the House Un-American Activities Committee and the Omnibus Crime Control and Safe Streets Act of 1968. See Adam H. Kurland, The Guarantee Clause as a Basis for Federal Prosecutions of State and Local Officials, 62 S. CAL. L. REV. 367, 446-52 (1989) (emphasis omitted). 
ism. As Cass Sunstein explains, republicanism is an effort to realize "a virtuous politics... without indulging unrealistic assumptions about human nature." 36 The possibility of such a politics is modeled in the United States Constitution's "complex set of precommitment strategies, through which the citizenry creates institutional arrangements to protect against political self-interest, factionalism, failures in representation, myopia, and other predictable problems in democratic governance." ${ }^{37}$ As the broad text of the clause suggests, the diversity of the ratifying states' forms of government confirms that the federal model was only one model, specially adapted to its federal functions, and not a casting mold to which the States would need to conform. ${ }^{38}$ The nation of state republicanisms under the Guarantee Clause is structuralist all the way down.

This is not to say that republicanism is indeterminate. Congress's authoritative construction of the Guarantee Clause played a critical role in conditioning the admission and readmission of states during Reconstruction on suffrage for freed slaves. ${ }^{39}$ Since then, other constitutional provisions have refined the guarantee, expressly extending it to include all races, ${ }^{40}$ women, ${ }^{41}$ the poor, ${ }^{42}$ young adults, ${ }^{43}$ and the People directly in choosing Senators. ${ }^{44}$ The Supreme Court supplemented these textual constitutional guarantees with long-established political rights

\footnotetext{
36. CASs R. SUnSTEIN, THE PARTIAL CONSTITUTION 21 (1993).

37. Id.

38. "'All the States had governments when the Constitution was adopted. In all the people participated to some extent, through their representatives elected in the manner specially provided. These governments the Constitution did not change. They were accepted precisely as they were, and it is, therefore, to be presumed that they were such as it was the duty of the States to provide. Thus we have unmistakable evidence of what was republican in form, within the meaning of that term as employed in the Constitution.'" Baker v. Carr, 369 U.S. 186, 222 n.48 (1962) (quoting Minor v. Happersett, 88 U.S. 162, 175-76 (1874)).

39. See Amar, supra note 27 , at 780-82.

40. U.S. CONST. amend. XV.

41. U.S. CONST. amend. XIX.

42. U.S. CONST. amend. XXIV.

43. U.S. CONST. amend. XXVI.

44. U.S. CONST. amend. XVII; see also U.S. CONST. amend. XXIII ("The District constituting the seat of government of the United States shall appoint in such manner as the Congress may direct: A number of electors of President and Vice President equal to the whole number of Senators and Representatives in Congress to which the District would be entitled if it were a State ....").
} 
derived from the First and Fourteenth Amendments, including the right to speak, associate, and petition on political issues, and a basic right to have one's vote count equally. Richard Hasen identifies these as a concept of essential political rights, and his conception distinguishes these core equality principles as "basic political equality rights [that] are absolutely essential for any government to function as a democracy." 45 Together with the republican guarantee, these rights set a floor of basic political equality, above which states may adapt their own form of government consistent with their own conceptions of political equality and other republican values. ${ }^{46}$

Beyond this consensus of basic political equality, republicanism is an essentially contested concept. ${ }^{47}$ No comprehensive conception of republicanism can exist outside of how any particular political community defines it at a particular time in its development. ${ }^{48}$ At a national level, however, no such conception holds. At least as long as scholars have recognized election law as a distinct field, they have debated the conflicting values republicanism is supposed to embody: accountability and participation, majority rule and minority representation, deliberation and responsiveness, equality and liberty of influence, legitimacy and self-expression, competition and

45. Richard L. HASEN, THE Supreme COURT AND Election LaW: Judging EQUALITY FROM BAKER V. CARR TO BUSH V. GORE 79 (2003).

46. See Guy-Uriel E. Charles, Constitutional Pluralism and Democratic Politics: Reflections on the Interpretive Approach of Baker v. Carr, 80 N.C. L. REV. 1103, 1156 (2002) ("[T]he Court in Baker set the floor for equality but not the ceiling. Presumably, by setting the floor, the Court permitted state actors to provide greater political equality, as many conceptions of political equality undoubtedly exist.").

47. See Samuel Issacharoff, Pamela S. Karlan \& Richard H. Pildes, The LAW OF Democracy: Legal Structure OF THE POlitical Process 1 (1998) ("There are many possible forms democracy can take, many different institutional embodiments of democratic politics."); Daniel H. Lowenstein, The Supreme Court Has No Theory of Politics - and Be Thankful for Small Favors, in THE U.S. SUPREME COURT AND THE Electoral PROCESS 283, 302 (David K. Ryden ed., 2d ed. 2002); Dan M. Kahan, Democracy Schmemocracy, 20 CARDOZO L. REV. 795 (1999).

48. See Elizabeth Garrett, Is the Party Over? Courts and the Political Process, 2002 SUP. CT. REV. 95, 152 ("Within the very broad outlines provided by the Constitution, courts should permit the political processes of local, state, and federal governments to work out their own precise forms of representative (and direct) democracy. These forms will doubtless vary from jurisdiction to jurisdiction and change over time."). 
stability, and so on. ${ }^{49}$ Standard accounts trace at least three distinct and conflicting republicanisms-civic republicanism, libertarianism, and pluralism - to Madison himself. What distinguishes the republican pluralism described here from other perfectionist forms of republicanism in election law is the political community that defines it. While many accounts of election law look to judges (usually federal judges) to weigh and resolve these conflicting republican values in state politics, ${ }^{50}$ republican pluralism acknowledges the guarantee is $a$ (one of many chosen by states), not the (one chosen by the federal government), republican form of government in the States.

Republican pluralism is pluralist in the ordinary sense that a republican form of government may exist in many distinct forms consistent with republicanism. It is also pluralist in the theoretical sense of embracing pluralism in politics among the States. These republicanisms are politically contested. Once one form satisfies the broad constitutional requirements of the Guarantee Clause and basic political equality, there is no criterion outside of politics itself to assess its desirability. In each state, that politics is partly a function of the republicanism it sustains. It is this latter theoretical sense that Bruce Cain emphasizes in proposing "reform pluralism," meaning first "a more explicitly pluralist political reform agenda" that takes a

49. See, e.g., Charles, supra note 46, at 1142 (identifying key principles of "majority rule, political participation, accountability, responsiveness, substantial equality, and interest representation"); Nicholas O. Stephanopoulos, Elections and Alignment, 114 COLUM. L. REV. 283, 356 (2014) (identifying, in addition to alignment of elected representatives with voter preferences, "protecting individual rights such as the franchise and the freedom to advocate one's political views; promoting electoral competition, especially when there is a danger of incumbent entrenchment; increasing voter participation, turnout in particular; respecting the political equality of all citizens; and ensuring that minorities are represented adequately in the halls of power."); see also Michael S. Kang, To Here from Theory in Election Law, 87 TEX. L. REV. 787, 797 (2009) (reviewing HEATHER K. GERKEN, THE DEMOCRACY INDEX: WHY OUR ELECTION SYSTEM IS FAILING AND HOW TO FIX IT (2009)) (asking whether "what seem like uncontroversial values in proposing that eligible voters should be able to vote and that all valid votes should be counted ... would become intense partisan struggles over voter registration, identification, and fraud when the debate is made more specific").

50. See, e.g., Charles, supra note 46, at 1162 ("[J]udges can-and must-utilize democratic theory to direct their interpretation of the Constitution."). 
realistic view of political contestation. ${ }^{51}$ Second, however, he also recommends "a blended approach" as "a kind of metapluralist principle" that recognizes the quantitatively plural distinctions a qualitatively pluralist politics creates when iterated across many governing institutions, including states..$^{52}$ This Article prioritizes the quantitative pluralism (or "metapluralism") reflected in the diversity of state republicanism forms and is more agnostic about the priority of qualitative pluralism among the possible republican values any one state realizes.

\section{B. Republican Perfectionism}

Compared with republican pluralism, republican perfectionism offers far more detailed (and contestable) constructions of the guarantee..$^{53}$ The sheer diversity of these conceptions reflects deep disagreements about the constitutional regulation of politics in general and the relationship of judicial review to that task in particular. The Guarantee Clause is not indeterminate, and Richard Hasen may put it too strongly when he says, "'Republicanism' is an empty vessel to be filled by whatever individual right the particular writer desires the courts to enforce." 54 But as Hasen suggests, any reading of the guarantee as a vessel for nationalizing individual civil rights (beyond individual political rights) misses its basic structural function as the Union's shield and not a sword. The history of the guarantee provides the backdrop to contemporary debates about republicanism that take place under more contested clauses.

51. BRUCE E. CAIN, DEMOCRACY MORE OR LesS: AMERICA's POLITICAL REFORM QUANDRY 195 (2015); see also Richard H. Pildes, Romanticizing Democracy, Political Fragmentation, and the Decline of American Government, 124 YALE L.J. 804, 827 (2014) ("Unless we attend to the ways in which political power is actually mobilized, organized, exercised, and marshaled, then policy proposals based on an individualistically driven vision of politics, or on non-grounded abstract democratic ideals such as 'participation,' or 'equality,' can perversely contribute to undermining our institutional capacity to govern.").

52. CAIN, supra note 51.

53. See, e.g., Heller, supra note 34, at 1754-55.

54. Richard L. Hasen, Leaving the Empty Vessel of "Republicanism" Unfilled: An Argument for the Continued Nonjusticiability of Guarantee Clause Cases, in THE POLITICAL QUESTION DOCTRINE AND THE SUPREME COURT OF THE UNITED STATES 75, 82 (Nada Mourtada-Sabbah \& Bruce E. Cain eds., 2007) (internal quotation marks omitted). 
In the past half-century, the argument for using the guarantee as the Union's sword against the States begins with Arthur Bonfield's hope expressed on the eve of Baker v. Carr that "the specific substance of republican government will be dictated by contemporary values." 55 His argument for broader political rights guaranteed as a form of republican government extended from abolition of the poll tax, to universal free public education, and then to "[e]qual access for all to housing, employment, education, transportation and numerous other things ...."56 This imperial conception of republicanism, Bonfield conceded, "might interfere a great deal in the internal governance of the states." 57 More recently, Erwin Chemerinsky argues that the Guarantee Clause should be an additional repository for federal courts to define and protect a similarly unenumerated, if not equally ambitious, set of "basic individual rights." 58 Thomas Berg proposes more modest national modifications of state republicanism under the Guarantee Clause. ${ }^{59}$ Berg sees national republicanism as an avenue to enhance democratic deliberation in the states by limiting delegation of the legislative process and by strengthening rational basis review of legislative results. ${ }^{60}$ However, these proposals are still quite remote from the core concerns of the clause.

Some readings of the clause do use the guarantee less as a sword against the States and more as a shield to protect the Union, as well as particular conceptions of republicanism in the States. Adam Kurland, for example, argues that the clause provides a positive grant of power supporting federal anticorruption legislation directed at state and local officials that is broader than what the Commerce Clause may allow. ${ }^{61}$ Unlike other theories of republicanism, he is careful not to read too much into the guarantee beyond its provision of a rational basis

55. Arthur E. Bonfield, The Guarantee Clause of Article IV, Section 4: A Study in Constitutional Desuetude, 46 MiNN. L. REV. 513, 560 (1962).

56. Id. at 564, 566 .

57. Id. at 570 .

58. Chemerinsky, supra note 2 , at 869.

59. Thomas C. Berg, The Guarantee of Republican Government: Proposals for Judicial Review, 54 U. CHI. L. REV. 208, 242 (1987).

60. Id.

61. Kurland, supra note 35 , at 446-52. 
for such legislation. ${ }^{62}$ In view of recent and not-so-recent history, criminalizing corruption at the state and local level may well be rationally related to preserving majority rule in, and protecting the Union from, corrupt state and local officials. ${ }^{63}$

Conversely, Deborah Jones Merritt argues for using the Guarantee Clause as a shield for state autonomy against encroachments on federalism values such as direct federal regulation of state governments. ${ }^{64}$ Indeed, this latter interpretation is one of the few proposals to gain at least limited traction in the Supreme Court. In New York v. United States, Justice O'Connor's opinion for the Court cited Merritt in partial support of an anticommandeering principle of federalism that ensures "state government officials remain accountable to the local electorate." 65 This conception of the Guarantee Clause instantiates a particular form of limited federal power beyond Article I enumerations and the Tenth Amendment canon of construction, possibly as a way to rework intergovernmental immunities. ${ }^{66}$ Yet these claims simply hand the inapt sword of republicanism from the Union to the States. Transforming the Guarantee Clause from a multipurpose tool for nationalizing rights into a multipurpose tool for decentralizing powers still misconceives the clause as a sword, not a shield.

Merritt also makes a more structurally grounded argument concerning the Guarantee Clause's relationship to other constitutional provisions. She recognizes that the primary federal constitutional constraints on the States' political structures are not found in the Guarantee Clause, but in other more direct requirements of basic political equality such as the Fourteenth,

62. Id. at 459

63. See, e.g., id. at 446-49 (describing Governor-Senator Huey Long's "totalitarian" state of Louisiana); Monica Davey \& Emma G. Fitzsimmons, Jury Finds Blagojevich Guilty of Corruption, N.Y. TIMES (June 27, 2011), http://www.nytimes. com/2011/06/28/us/28blagojevich.html?_r=0 [http://perma.cc/549M-22CE] ("A jury on Monday convicted Rod R. Blagojevich, the former governor of Illinois, of a broad pattern of corruption, including charges that he tried to personally benefit from his role in selecting a replacement for President Obama in the United States Senate.").

64. Deborah Jones Merritt, The Guarantee Clause and State Autonomy: Federalism for a Third Century, 88 COLUM. L. REV. 1, 69-70 (1988).

65. 505 U.S. 144, 185 (1992).

66. Merritt, supra note 64 , at 55-58. 
Fifteenth, Nineteenth, Twenty-Fourth, and Twenty-Sixth Amendments. ${ }^{67}$ Merritt argues that beyond these specific requirements, "in the guarantee clause the United States promises to secure each of the states the autonomy necessary to maintain a republican form of government." 68 According to Merritt, a republican government "is responsible to its voters rather than to any outside agency." 69 Therefore, "[i]n order to ensure that state and local governments remain responsive to their constituents, those citizens must have the power to choose the governmental forms that work best for them."70 In other words, the conception of the Guarantee Clause as a national shield to protect the Union's republicanism includes its guarantee that it will not be used as a sword to attack States' republicanisms.

Jacob Heller draws a similar distinction between "republicanism top-down and bottom-up," 71 though he has greater concerns about the state of republicanism in the States. Arguably dysfunctional state governments such as California's lead him to several "top-down" uses of the Guarantee Clause as a sword. He would construe it to empower federal anticorruption legislation ${ }^{72}$ (following Adam Kurland), ${ }^{73}$ to require one-person one-vote apportionment ${ }^{74}$ (following Michael McConnell), ${ }^{75}$ and to support federal preclearance requirements for state election law changes under $\S 5$ of the Voting Rights Act $^{76}$ (following Richard Hasen). ${ }^{77}$ Most ambitiously, Heller reads the clause to prohibit "legislative power grabs" that undermine the States' administrative agencies ${ }^{78}$ and "ballot-box budgeting" through California's spending initiatives. ${ }^{79}$

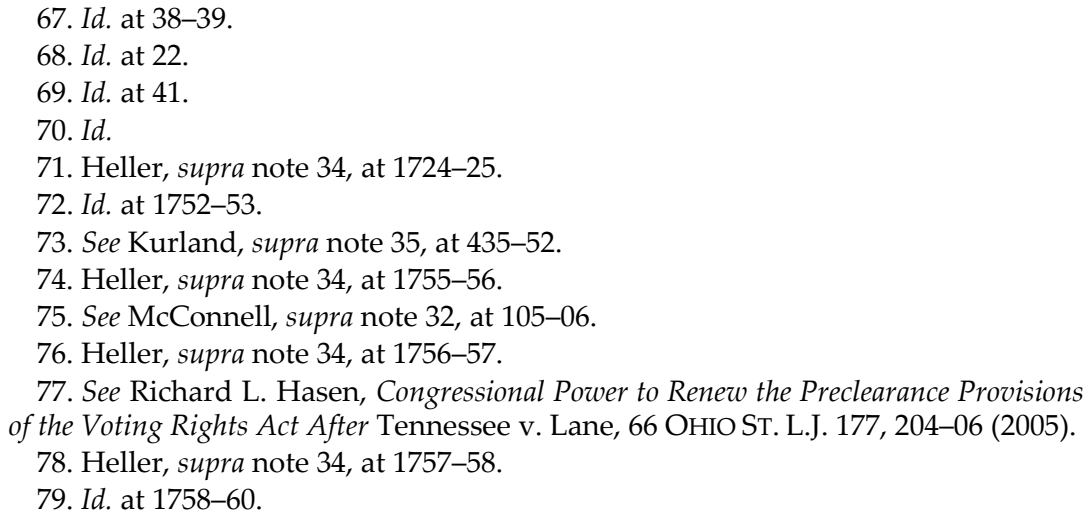


The first three applications qualify as core uses of the clause as a "shield" to protect the Union against non-republican forms of corrupt or non-majoritarian government in the States. The last two might qualify as a shield only in the extreme instances when it is clear, as Heller suggests, that a state's republican form of government is suffering "death by a thousand cuts" through an excess of administrative and fiscal micromanagement by law and initiative. ${ }^{80}$ While Heller's prescription may be overbroad with respect to the initiative process, ${ }^{81}$ it recognizes what most commentators miss in the text of the Guarantee Clause: that "[it] does not apply to those matters not touching on a state's form of government[,]" such as public education or individual rights. ${ }^{82}$

Like Merritt's argument that the Guarantee Clause implies some level of state autonomy in choosing its republican form of government, Heller's “bottom-up" approach would deny the federal government a sword against state governments in at least one notable application. In Agua Caliente Band of Cahuilla Indians v. Superior Court, ${ }^{83}$ the California Supreme Court denied a tribe federal common-law sovereign immunity from a state political practices investigation, holding that the Guarantee Clause shielded the state's political process from interference by federal immunity. ${ }^{84}$ Heller argues, convincingly, that this use of the clause might serve as a model to shield state campaign finance laws from the same level of scrutiny applied to federal campaign finance laws. ${ }^{85}$ The federal government ideally represents the strongest republican form of government due to its own structural guarantees (including its enlarged sphere of representation) "that help prevent corruption from interfering with representation or majority will." 86 As Madison originally recognized, the same cannot be said for the States, and strong federal constitutional attacks against the States' own anti-corruption shields

80. Id. at 1759 .

81. Compare Heller, supra note 34 , at 1759 with Natelson, supra note 32, at 831-35 (arguing that the initiative power is consistent with the republican form of government).

82. Heller, supra note 34 , at 1760.

83. 148 P.3d 1126 (Cal. 2006).

84. See id. at 1136-39.

85. Heller, supra note 34 , at 1754-55.

86. Id. at 1755. 
not only distort the republican principles embodied in the freedom of speech, ${ }^{87}$ but also may subvert the Guarantee Clause.

An emergent case serves as a reminder of the potential perils that may arise from a perfectionist reading of the Guarantee Clause. A century ago, the Supreme Court rejected a Guarantee Clause challenge to Oregon's initiative process. ${ }^{88}$ Notably, it did not do so on the grounds that the initiative was consistent with a republican form of government, but only that the question was "embraced within the scope of the powers conferred upon Congress, and not therefore within the reach of judicial power," potentially leaving the federal government open to regulate the state initiative process. ${ }^{89}$ Former Oregon Supreme Court Justice Hans Linde argues that the initiative, when "misused" for certain purposes, violates the Guarantee Clause. ${ }^{90}$ Apparently, no court had revisited this question until Kerr $v$. Hickenlooper, a challenge to Colorado's "Taxpayer Bill of Rights" (TABOR) constitutional initiative. ${ }^{91}$ On appeal, the Tenth Circuit held that the Guarantee Clause is judicially enforceable and, in light of the ample interpretative tools offered by originalism, susceptible to "judicially discoverable and manageable standards." 92 The court was careful on an interlocutory appeal not to address the merits of the plaintiffs' claim that TABOR "undermines the fundamental nature of the state's Republican Form of Government," 93 but the Supreme Court vacated the judgment ${ }^{94}$ and remanded the case for further consideration in light of Arizona State Legislature v. Arizona Independent Redistricting Commission. ${ }^{95}$ Still, such a sweeping attack on a state constitution lies well beyond what is necessary for

87. See Anthony Johnstone, A Madisonian Case for Disclosure, 19 GEO. MASON L. REV. 413, 462-65 (2012).

88. See Pacific States Tel. \& Tel. Co. v. Oregon, 223 U.S. 118 (1912).

89. Id. at 151.

90. Hans A. Linde, Who Is Responsible for Republican Government?, 65 U. COLO. L. REV. 709 (1994). But see Natelson, supra note 32, at 831-55 (arguing that the initiative is consistent with the Guarantee Clause).

91. 744 F.3d 1156 (10th Cir. 2014).

92. Id. at 1174 .

93. Id. at 1162 .

94. Hickenlooper v. Kerr, 135 S. Ct. 2927 (2015) (memorandum opinion).

95. 135 S. Ct. 2652 (2015). 
preservation of the Union or protection of basic political equality. It exemplifies republican perfectionism.

\section{The NATIONALIZATION OF StATE POLITICS}

The lack of meaningful consensus on the interpretation of the republican guarantee among scholars has not prevented the national government from attempting to impose various versions of republicanism masquerading as other federal powers and rights. The dominant constitutional story tells of perfecting the processes of democracy through representation-reinforcing federal judicial intervention against legislation, especially state legislation, that distorts the political process. ${ }^{96}$ An extended narrative includes congressional enactment and federal enforcement of voting rights and campaign finance reform legislation and, more broadly, the proposal by Congress and ratification by the States of constitutional amendments extending voting rights. Throughout, the Supreme Court, abetted by Congress (or the reverse, depending on the telling), champions the Constitution's evolving promise of ever-more-equal citizenship in an ever-more-perfect republic.

This story, much of which has become true, is near its end. While substantial regression is unlikely given the hard-won settlement of basic political equality expressed in constitutional amendments and enforcing legislation, ${ }^{97}$ federal progress beyond this settlement has run its course under the current constitutional regime. This settlement is the Union's national shield against anti-republicanism, and it remains strong in guaranteeing within a reasonable range republican pluralism in the States. Beyond this shield, no clear or coherent constitutional vision guides the Supreme Court or Congress to pick up the sword and fight for any particular republican perfectionism. If it ever did, process theory no longer constrains courts, no longer supports a consensus on its normative commitments,

96. See generally JOHN HART ELY, DEMOCRACY AND DISTRUST: A THEORY OF JUDICIAL REVIEW (1980).

97. See, e.g., U.S. CONST. amends. XIV, XV, XIX, XXIV, \& XXVI; Voting Rights Act of 1965, 52 U.S.C. $\S 10101$ et seq. But see infra note 264 and accompanying text (discussing the hobbling of $\S 5$ of the Voting Rights Act). 
and no longer provides usable policy guidance. ${ }^{98}$ To the contrary, the constitutional law of the political process is highly contested within the Supreme Court and between the Court and Congress.

The story, termed "the constitutionalization of democratic politics," 99 may be better understood as the nationalization of state politics, defined broadly as the inclusion of the entire political structure of a state including its means of electing federal officials. The national government "did not just judicialize election administration" and other aspects of state political structure, it "also federalized election litigation, moving much of it from state to federal courts." 100 What distinguishes the end of this story from its beginning is not that it is constitutional, but that it is national to the exclusion of, and often at the expense of, the states in a federal system.

The nationalization project has not failed. Rather, it helped establish the basic political equality of previously unrepresented or underrepresented citizens. ${ }^{101}$ This strengthened the Union's shield against sectionalism that denied broad classes of the national population representation in our national and state politics. It may be true that federal courts' current construction of constitutional law "does both too much-by inappropriately extending rights doctrines into the design of democratic institutions - and too little-by declining to address self-entrenching laws aggressively enough." 102 Yet given the nation's substantial progress toward political equality, there is no longer reason to expect that the continued nationalization of state politics will do any better than devolution to the States at further advancing republican values, no matter how hard federal courts work to get the constitutional law right. At the same time, there are a number of reasons to expect that nationalization has done, and will continue to do, worse by imposing "constraints on what

98. See HASEN, supra note 45 , at 4-6.

99. See Richard H. Pildes, Foreword: The Constitutionalization of Democratic Politics, 118 HARV. L. REV. 29, 31(2004).

100. Daniel Tokaji \& Owen Wolfe, Baker, Bush, and Ballot Boards: The Federalization of Election Administration, 62 CASE W. RES. L. REV. 969, 984 (2012).

101. See generally David Strauss, Is Carolene Products Obsolete?, 2010 U. ILL. L. REV. 1251 (2010).

102. Pildes, supra note 99 , at 41. 
should be acceptable experimentation in the design of democracy." 103 Attempts to perfect any single vision of republicanism on a national scale, rather than to sustain plural visions of republicanism at the state scale, risk undermining the latter without achieving the former. The shield's work is largely done in guaranteeing republican forms of government in the States, so it may be time for the Union to sheathe its sword.

\section{A. Congressional Nationalization}

Congress is responsible for the most concrete advancements of basic political equality through nationalization. Beyond the significant impact of the Voting Rights Act and subsequent relatively minor administrative reforms, ${ }^{104}$ however, Congress's greatest democratic achievements have been its partnerships with the States in amending the Constitution to establish a textual basis for basic political equality. Even with its own enforcement powers under those Amendments, its contribution does not extend far beyond the Voting Rights Act itself. Section 2 of the Fourteenth Amendment, ${ }^{105}$ the Constitution's most explicit and self-executing republican promise of an expanded franchise (though compromised at the expense of women), has become a dead letter.

Congress's record in campaign finance reform is less inspiring. Even where it has been bold, as with the Bipartisan Campaign Reform Act of 2002 (BCRA), it has not been particularly innovative. The centerpiece of Progressive Era campaign finance reform, the Corrupt Practices Act regulating corporate

103. Id. at 55 .

104. See, e.g., The Uniformed and Overseas Citizens Absentee Voting Act, Pub. L. No. 99-410, 100 Stat. 924 (1986); National Voter Registration Act of 1993, Pub. L. No. 103-31, 107 Stat. 77 (1993); Help America Vote Act of 2002, Pub. L. No. 107252, 116 Stat. 1666 (2002).

105. "[W] hen the right to vote at any election ... is denied to any of the male inhabitants of such State, being twenty-one years of age, and citizens of the United States, or in any way abridged, except for participation in rebellion, or other crime, the basis of representation therein shall be reduced in the proportion which the number of such male citizens shall bear to the whole number of male citizens twenty-one years of age in such State." U.S. CONST. amend. XIV, § 2. See Franita Tolson, What is Abridgment?: A Critique of Two Section Twos, 67 ALA. L. REV. 433, 434 (2015) ("This provision, which has never been enforced, provides that Congress can reduce a state's delegation in the House of Representatives for denying or abridging the right to vote in almost any election - state or federal-on almost any grounds, with the exception of the commission of a crime."). 
and other campaign funding, was not a product of the federal government. Instead, it was conceived in the States and widely adopted by the early twentieth century when federal campaign finance legislation was still in its self-regulatory infancy. ${ }^{106}$ Beyond BCRA, which the Supreme Court and the hydraulics of campaign finance ${ }^{107}$ largely thwarted, Congress has either proceeded incrementally (the Help America Vote Act in 2002) or reiteratively (the Voting Rights Act reauthorization in 2006). Even such modest advances seem ambitious relative to the current pace and scope of federal legislation.

More importantly for campaign finance and Congress's structuring of republicanism in general, the unintended system resulting from the interaction of legislation, judicial review, and executive inaction is paralyzed by hyperpolarization that makes even minor reforms impossible. ${ }^{108}$ As Lawrence Lessig explains, "The forces that would block [reform] work well and effectively on Capitol Hill, and inside the Beltway. That is their home."109 For the few reforms where consensus might otherwise be possible, such as election assistance to states, malfunctioning budget and appointments processes prove insurmountable. ${ }^{110}$

106. See LOUISE OVERACKER, MONEY IN EleCtIONS 294-95 (1932); Robert E. Mutch, Before and After Bellotti: The Corporate Political Contribution Cases, 5 ELECTION L.J. 293, 293 n.1 (2006).

107. See generally Samuel Issacharoff \& Pamela S. Karlan, The Hydraulics of Campaign Finance Reform, 77 TEX. L. REV. 1705 (1999).

108. See Richard H. Pildes, Why the Center Does Not Hold: The Causes of Hyperpolarized Democracy in America, 99 CAL. L. REV. 273 (2011).

109. LAWRENCE LESSIG, REPUBliC, LOST: HOW MONEY CORRUPTS CONGRESSAND A PLAN TO STOP IT 275 (2011). See also Richard Pildes, The Future of Voting Rights Policy: From Anti-Discrimination to the Right to Vote, 49 How. L.J. 741, 763 (2006) (Conceding at the time of the 2006 Voting Rights Act reauthorization, "There is simply no constituency ... to ask hard questions about what the future of voting rights ought to look like. Instead, there is every incentive for the critical actors to avoid these questions altogether.").

110. See, e.g., Amanda Becker, The Phantom Commission: Agency Formed to Restore Confidence Is in Disarray, Roll CALL (Nov. 1, 2012), http://www.rollcall.com /issues/58_33/Agency-Formed-to-Restore-Confidence-in-Elections-Is-in-Disarray218616-1.html [http://perma.cc/MRE3-D6XR] (describing the U.S. Election Assistance Commission on its tenth anniversary thus: "Its four commissioner spots are vacant. The executive director resigned last year. Its general counsel left in May. It has lacked a quorum to conduct official business for almost two years. Congressional gamesmanship has hamstrung the commission by neither giving it necessary resources nor eliminating it outright."). 


\section{B. Executive Nationalization}

The federal legislation with the most transformative potential in the areas of voting rights and campaign finance faces uneven enforcement in the executive branch. The Voting Rights Act produced a record of uneven enforcement, particularly under the now impotent preclearance requirements of Section 5. ${ }^{111}$ The lead enforcer and interpreter of federal campaign finance law, the Federal Election Commission (FEC), is subject to partisan nonenforcement by its deadlocked design; ${ }^{112}$ the only serious dispute is whether that is a good or a bad thing. More work might be done on the causes and effects of partisan enforcement of federal election law, but suffice it to say that some campaign finance reform advocates view the Securities and Exchange Commission, or even the Internal Revenue Service, as a more promising enforcer of political transparency than the FEC. ${ }^{113}$

\section{Judicial Nationalization}

The Supreme Court stands at the center of the federal government's nationalization of state politics. Its banner was once the Carolene Products doctrine of heightened scrutiny for state legisla-

111. See Samuel Issacharoff, Is Section 5 of the Voting Rights Act a Victim of Its Own Success?, 104 ColuM. L. ReV. 1710 (2004); see also Daniel P. Tokaji, If It's Broke, Fix It: Improving Voting Rights Act Preclearance, 49 How. L.J. 785, 798-819 (2006).

112. See Trevor Potter, How the FEC Can Stop the Tidal Wave of Secret Political Cash, WASH. POST (Nov. 16, 2012), https://www.washingtonpost.com/opinions /how-the-fec-can-stop-the-tidal-wave-of-secret-political-cash/2012/11/16/966c48cc2dae-11e2-89d4-040c9330702a_story.html [http://perma.cc/7YAZ-V77M] ("It is the FEC and the permissive regulations it has created over the past decade that have allowed close connections between candidates, parties and political action committees. And it is the agency's dysfunctional state-engineered by a Republican congressional leadership adamantly opposed to campaign finance reform - that has turned the Supreme Court's promise of transparency into a joke.").

113. Lucian Bebchuk \& Robert Jackson Jr., Shining Light on Corporate Political Spending, 101 GEO. L. J. 923 (2013) (arguing for the SEC to develop rules requiring that public companies disclose their spending on politics); Jonathan Weisman, Scrutiny of Political Nonprofits Sets Off Claim of Harassment, N.Y. TIMES (Mar. 6, 2012), http://www.nytimes.com/2012/03/07/us/politics/irs-scrutiny-of-politicalgroups-stirs-harassment-claim.html [http://perma.cc/9ZHJ-94J7]. But see Treasury Inspector General for Tax Administration, Inappropriate Criteria Were Used to Identify Tax-Exempt Applications for Review, Ref. No. 2013-10-053 (May 14, 2013) ("The IRS used inappropriate criteria that identified for review Tea Party and other organizations applying for tax-exempt status based upon their names or policy positions instead of indications of potential political campaign intervention."). 
tion that "restricts those political processes which can ordinarily be expected to bring about repeal of undesirable legislation."114 Yet even Reynolds $v$. Sims, ${ }^{115}$ the initial stage of clearing the most widespread political process blockage of malapportionment, did not advance any effective conception of republicanism beyond an important but technical rule of "one-person, one-vote" that has been overwhelmed by redistricting technology. ${ }^{116}$

We are not likely to see the Court create a republican representational principle on the scale of Reynolds again anytime soon. With one notable but self-limiting exception, ${ }^{117}$ the Supreme Court has excused itself from the political thicket of justiciable political equality under the Fourteenth Amendment. ${ }^{118}$ More recent racial and political gerrymandering cases suggest the reapportionment revolution's legacy of a justiciable and substantive standard of political equality may not progress farther than a strict quantitative, not qualitative, standard. ${ }^{119}$ Notably, the Court in Evenwel v. Abbott appeared to defer to the consensus practice in the States by rejecting a claim that the Fourteenth Amendment requires states to use voter population, rather than total population, in apportioning state legislative districts. ${ }^{120}$ Once again, however, the unanimous judgment's seeming endorsement of that consensus concealed deep divisions in the

114. United States v. Carolene Products Co., 304 U.S. 144, 152 n.4 (1938).

115. 377 U.S. 533 (1964).

116. See Pamela S. Karlan, The Rights to Vote: Some Pessimism About Formalism, 71 TEX. L. REV. 1705 (1993).

117. Bush v. Gore, 531 U.S. 98 (2000).

118. But see Ne. Ohio Coal. For the Homeless v. Husted, 696 F.3d 580 (6th Cir. 2012) (holding that denial of the vote for voting at the wrong polling place due to poll worker error violated the Equal Protection Clause); Obama for Am. v. Husted, 697 F.3d 423 (6th Cir. 2012) (holding that contracting the early voting period for all voters except certain military voters violated the Equal Protection Clause). These cases may represent a kind of republican pluralism to the extent they arise from panels of regionally based circuit courts, rather than the centralized Supreme Court.

119. See Ala. Leg. Black Caucus v. Alabama, 135 S. Ct. 1257, 1272 (2015) (remanding potential racial gerrymandering claims for district-by-district reconsideration, and reserving the question whether intentional use of race in redistricting triggers strict scrutiny).

120. Evenwel v. Abbott, No. 14-940 (U.S. Apr. 4, 2016), slip op. at 18 (“Adopting voter-eligible apportionment as constitutional command would upset a wellfunctioning approach to districting that all 50 States and countless local jurisdictions have followed for decades, even centuries."). 
Court's approach to state republicanism. It drew a concurrence from Justice Thomas that invoked the Guarantee Clause directly:

As the Framers understood, designing a government to fulfill the conflicting tasks of respecting the fundamental equality of persons while promoting the common good requires making incommensurable tradeoffs. For this reason, they did not attempt to restrict the States to one form of government. Instead, the Constitution broadly required that the States maintain a "Republican Form of Government." But the Framers otherwise left it to States to make tradeoffs and reconcile the competing goals. ${ }^{121}$

The relative uniformity of state apportionment practices allowed the Court in Evenwel to avoid a choice between respecting state practices as legitimate expressions of diverse republican pluralism on the one hand, and using those practices as evidence of uniform republican perfectionism on the other. It remains to be seen which approach will predominate if and when a state departs from the consensus practice.

The Court's other interventions in political party, ballot access, and voting administration cases work only at the margins of a complex system of partisan politics, and as with gerrymandering, the Court has signaled its reluctance to intervene further. ${ }^{122}$ Even setting aside its long history of narrowly construing possible constitutional bases for expanding the franchise, the Court's record on Congress's constitutional extension

121. Id. slip op. at 12 (Thomas, J., concurring in the judgment) (citation omitted); see also id. slip op. at 2-3 (Alito, J., concurring in the judgment) ("[An argument that the Constitution requires either population-based or voted-based apportionment] implicates very difficult theoretical and empirical questions about the nature of representation. For centuries, political theorists have debated the proper role of representatives, and political scientists have studied the conduct of legislators and the interests that they actually advance. We have no need to wade into these waters in this case, and I would not do so."). With similar concern, Derek Muller notes that the Court's opinion in Evenwel "used strong language on its views of political theory . . . as if these were the Court's settled beliefs on how political representation ought to be." Derek Muller, Response, Evenwel v. Abbott, GEO. WASH. L. REV. DOCKET (Apr. 5, 2016), http://www.gwlr.org/evenwel-vabbott-a-new-attempt-to-define-one-person-one-vote/ [http://perma.cc/45FBHVW2]. See generally Derek T. Muller, Perpetuating "One Person, One Vote" Errors, 39 HARV. J.L. \& PUB. POL'Y 371 (2016).

122. See Wash. St. Grange v. Wash. St. Republican Party, 552 U.S. 442 (2008); Crawford v. Marion Cty. Election Bd., 553 U.S. 181 (2008). 
of voting rights is mixed. ${ }^{123}$ In Shelby County v. Holder, the Court exposed basic disagreements about the role of Congress and itself in assessing, let alone guaranteeing, political equality in the States. ${ }^{124}$ In so doing, it revealed again that the Court participates in, rather than adjudicates, the contest between particular forms of republicanism at the national level.

Notwithstanding the theoretical attraction of extending judicial representation-reinforcement to police the political process further, the actual Court has provided little reason to believe it could articulate and implement a coherent theory of republicanism. ${ }^{125}$ The Court may not do much better than the current state political institutions it polices so as to justify displacing them. ${ }^{126}$ Indeed, as Edward Foley argues, "[T]here is no guarantee that constitutional constraints designed to curb partisan favoritism in the legislature will be implemented in a nonpartisan manner by conventional courts, whether elected or appointed." 127 Beyond enforcing the thin settlement of basic political equality achieved through constitutional amendments credited equally to Congress and to some measure the ratifying states, the Court as an institution has proven itself incapable of nationalizing state politics to the end of perfecting any particular form of republicanism. The incoherence is as broad as it is deep, extending to comprehensively researched yet divided decisions on fundamental questions of politics like term limits and pamphleteering. ${ }^{128}$

123. Compare Harper v. Va. St. Bd. of Elections, 383 U.S. 663 (1966) with Oregon v. Mitchell, 400 U.S. 112 (1970), abrogated by U.S. CONST. amend. XXVI.

124. 133 S. Ct. 2612 (2013).

125. Campaign finance is a leading example. See Richard L. Hasen, Citizens United and the Illusion of Coherence, 109 MICH. L. REV. 581 (2011).

126. See Richard L. Hasen, Judges as Political Regulators: Evidence and Options for Institutional Change, in RACE, REFORM, AND REGULATION OF THE ELECTORAL PROCESS: RECURRING PUZZLES IN AMERICAN DEMOCRACY 101 (Guy-Uriel E. Charles, Heather K. Gerken \& Michael S. Kang eds., 2011).

127. Edward B. Foley, The Separation of Electoral Powers, 74 MONT. L. REv. 139, 144 (2013).

128. For two notable examples occurring in a single Term, see U.S. Term Limits, Inc. v. Thornton, 514 U.S. 779 (1995) (invalidating state term limits for federal officials under the Qualifications Clauses by a vote of 5-4, with detailed examinations of history and practice on both sides); McIntyre v. Ohio Elections Comm'n, 514 U.S. 334 (1995) (invalidating ballot issue campaign attribution law under the First and Fourteenth Amendments by a vote of 7-2, with Justice Thomas concurring and Justice Scalia dissenting on originalist grounds). For a more recent example, see Doe v. Reed, 561 U.S. 186 (2010) (upholding state law allowing ballot issue 
Meanwhile, the Court's scrutiny of modern campaign finance reform efforts has transformed the First Amendment's republican values of democratic opportunity into libertarian values of a pluralist political marketplace. ${ }^{129}$ According to the Court's view in Citizens United v. Federal Election Commission, "[d]emocracy is premised on responsiveness[,]" and "[i]t is in the nature of an elected representative to favor certain policies, and, by necessary corollary, to favor the voters and contributors who support those policies."130 Although the dissent credited the majority with entrenchment concerns reflecting a broader republican suspicion of "an incumbency protection plan," it had to turn to an earlier case to find them. ${ }^{131}$ The Court extended its pluralist (but not pluralism-respecting) theory of representation in McCutcheon v. Federal Election Commission, a case involving the right of a constituent of one representative to contribute to an unlimited number of representatives of other constituencies, with what appears to be a bold reframing of the American tradition of representation: "[C]onstituents [of the government but not of the candidate] support candidates who share their beliefs and interests, and candidates who are elected can be expected to be responsive to those [donors' not constituents'] concerns." 132 The Court's general theory of republicanism expressed in these campaign finance cases supports its easy elision of federal and state politics ${ }^{133}$ and may undermine federalism by opening the States' distinct republicanisms to further nationalizing forces. ${ }^{134}$

signature petition disclosure by an 8-1 vote, but splintering into four concurrences joined by six justices and a dissent).

129. See Johnstone, supra note 87.

130. Citizens United v. Fed. Election Comm'n., 558 U.S. 310, 359 (2010) (quoting McConnell v. Fed. Election Comm'n., 540 U.S. 93, 297 (2003) (Kennedy, J., dissenting in part)).

131. Id. at 460 (Stevens, J., dissenting).

132. 134 S. Ct. 1434, 1441 (2014).

133. See Am. Tradition Partn., Inc. v. Bullock, 132 S. Ct. 2490, 2491 (2012) (per curiam) (holding that "[ $t$ ]here can be no serious doubt" that the Court's analysis of the Bipartisan Campaign Reform Act of 2002 applies identically to Montana's popularly enacted Corrupt Practices Act of 1912); see generally Anthony Johnstone, The State of the Republican Form of Government in Montana, 74 MONT. L. REV. 5 (2013).

134. See Garrick B. Pursley, The Campaign Finance Safeguards of Federalism, 63 EMORY L.J. 781 (2014) (arguing that the rise of Super PAC spending of unlimited 
In one recent case, a different composition of the Court suggested it may be unwilling, in some circumstances, to move state election law further toward nationalization. Arizona State Legislature v. Arizona Independent Redistricting Commission presented the question of whether an independent redistricting commission enacted by popular initiative qualified under the Elections Clause as a "Legislature" competent to prescribe the "Times, Places and Manner" of congressional elections. ${ }^{135}$ In Madison's terms, the case asked whether the Constitution uses "Legislature" in the Elections Clause in a national sense (for the nation) or a federal sense (for the state in confederation). Despite the apparently clear text, and with the benefit of a close analysis of constitutional structure and history, the Court read the Clause in its federal sense, and left to the States the power to govern federal elections - in the absence of congressional action-according to their own view of the legislative power in a republic.

Other cases on the horizon will present similar questions and again invite the Court to nationalize new rules of state republicanism. The Court avoided reaching the merits of Kerr v. Hickenlooper, but not without acknowledging the potential justiciability of its Guarantee Clause claim in a footnote to Arizona State Legislature. ${ }^{136}$ That provocative citation, and Justice Thomas's invocation of the Guarantee Clause in Evenwel, suggests the Court will continue to engage the arguments between republican perfectionism and republican pluralism, perhaps with a helpful return to the constitutional text. As the Court reconsiders the justiciability of the Guarantee Clause, its text serves as an important reminder of its function as the Union's shield for the defense against anti-republicanism in the States, and not as the Union's sword for the imposition of a particular republicanism on the States.

amounts across state lines erodes the links between federal representatives and their state constituencies, weakens parties as a vector for influence by state parties over national politics, and may drown out traditional intergovernmental lobbies that speak for the States).

135. 135 S. Ct. 2652 (2015).

136. Id. at 2660 n.3 (citing New York v. United States, 505 U.S. 144, 185 (1992)) ("[P]erhaps not all claims under the Guarantee Clause present nonjusticiable political questions."). 


\section{THE DISTINCTIVENESS OF STATE REPUBLICANISMS}

National republicanism may be incoherent, but is state politics any different or better? Distinct state republicanism may be merely a romantic notion overtaken by centralizing legal and political forces. ${ }^{137}$ Once, perhaps, states constituted distinct political communities, but those were long ago displaced by factional interests working on a national scale. On this account, the mobility of individuals, parties, and campaign funds renders states as scenery on the national political stage. More pessimistically, even if states satisfy the constitutional requirements of basic political equality, distinct state republicanism only masks the partisan capture of state election laws for purely factional ends. ${ }^{138}$ Drawing on Madison's suspicion of the factional disease afflicting state politics, this account finds the necessary republican cure at the national level. As bad as it might be at the national level, the argument goes, it is worse in the States.

Like other claims grounded in federalism principles, the existence and desirability of republican pluralism in the States depends on a significant degree of state autonomy in formulating election law. That legal autonomy must be more than theoretical or merely out of lockstep with federal law. It should be demonstrated in practice, producing "laboratories of democra$\mathrm{cy}^{\prime \prime}$ in the truest sense of those words. That legal practice should be consequential, associated with diverse political cultures either preserved by or producing distinct systems of elec-

137. See, e.g., James A. Gardner, The Myth of State Autonomy: Federalism, Political Parties, and the National Colonization of State Politics, 29 J.L. \& POL. 1 (2013) (arguing that the rise of the national political parties has led to the colonization of state politics to the exclusion of political autonomy); Edward Rubin \& Malcolm Feeley, Federalism: Some Notes on a National Neurosis, 41 UCLA L. REV. 903 (1994) (arguing that states do not constitute significant political communities distinct from the national political community).

138. In an illuminating argument, Yasmin Dawood defines and criticizes the "partisan state," where partisanship not only dominates "first-order" general policy consistently with democratic theory, but also dominates "second-order" electoral policy inconsistently with self-government. Yasmin Dawood, Democracy and the Problem of the Partisan State, in LOYALTY: NOMOS LIV 257, 258-59 (Sanford Levinson et al. eds., 2013); see also Joshua Douglas, (Mis)Trusting States to Run Elections, 92 WASH. U. L. REV. 553 (arguing federal judicial deference has encouraged states to adopt laws rigged to benefit the party in power); Justin Levitt, Election Deform: The Pursuit of Unwarranted Electoral Regulation, 11 ELECTION L.J. 97 (2012). 
tion law. Only then, if states are both legally and culturally distinctive, can we turn to an assessment of whether those distinctions are valuable to state and national politics.

It is worth asking, when we are this far along in the nationalization of state politics, if distinct state political cultures with distinct state conceptions of republicanism are becoming obsolete. The same financial and political forces that drive federal gridlock push money, political consultants, campaign advertising, and increasingly legislation out to the States, while exerting a gravitational pull on state-level politicians toward Washington, D.C. Recently, William Marshall concluded, "The uniqueness of a state's political culture and therefore the need to preserve it ... may be rapidly becoming a relic of the past." 139 Yet the persistence of states as distinct political systems - the persistence of republican pluralism - is hard-wired into national politics in several constitutional and extra-constitutional ways. Most obviously, after all the outside campaign money is spent, even Congress still must be elected "by the People of the several States," and presidential electors must be appointed in a manner directed by state legislatures. ${ }^{140}$ Aside from this basic electoral connection, the discussion below reviews the range of policies and practices in which states remain distinct from each other and from the national government.

The strongest claim opposing distinct state republicanisms, that we have only one national republicanism, is overstated at least. National republicanism relies on distinct state rules for voting qualifications, election administration, political party organization, and districting. Even the broadest federal preemption under the Elections Clause, by a hypothetical Congress with an unprecedented appetite for centralization, could

139. William P. Marshall, The Constitutionality of Campaign Finance Regulation: Should Differences in a State's Political History and Culture Matter?, 74 MONT. L. REV. 79, 100 (2013).

140. U.S. CONST. art. I, § 2; U.S. CONST. art. II, § 1; U.S. CONST. amend. XVII. Notably, the slates of presidential electors are determined by nominating primaries and caucuses held in just a handful of states at a time and controlled by each state's distinct political party structure. The first states to cast votes are culturally distinct from the nation as a whole. See Asma Khalid, The Perfect State Index: If Iowa, N.H. Are Too White To Go First, Then Who?, NPR.ORG (Jan. 29, 2016), http://www.npr.org/2016/01/29/464250335/the-perfect-state-index-if-iowa-n-h-aretoo-white-to-go-first-then-who [http://perma.cc/2EHE-GH2S]. 
not entirely displace the States' role in national elections. Practically, moreover, "Congress has left much of its arguable power over election law on the table unused ...."141 In state elections, local campaign finance and lobbying laws come into play, as does a typically longer slate of elected offices and broader calendar of election dates. It is possible that pressure from national parties and interest groups could compress any possible political distinctions into an undifferentiated mass of election law reflecting a national republicanism. But the policies and practices in the States do not bear this out. There remain important, persistent distinctions among the legal regimes of state republicanisms, and these regimes produce and are preserved by distinct political cultures.

\section{A. Legal Distinctions}

An American today experiences more variation in elections than she does in just about any other aspect of her participation in mass culture, from what is playing on the radio when the alarm goes off, to the coffee shop, to the morning commute, to the workplace, to the lunch out, to the shopping trip on the way home, to the street where she lives. Within broad ranges of urban, suburban, and rural culture, these ordinary experiences may be indistinguishable. Yet on Election Day, everything changes.

Most of these distinctions are not merely functions of election officials' competence or best practices. There are vast and troubling variations in competence, to be sure. The legitimate breadth of these policy variations is telling, however. The leading bipartisan and nonpartisan efforts at election reform reach consensus on a number of effective "one size fits all" election metrics and rules, but they avoid the deeper value judgments (or partisan calculations) reflected in voter ID laws or particular means of early voting, let alone party rules and campaign

141. Kirsten Nussbaumer, The Election Law Connection and U.S. Federalism, 43 PUBLIUS: J. FEDERALISM 392, 395 (2013) (arguing that Congress forbears because state legislators represent an important constituency for members of Congress, who may owe their careers not only to their formative years of work within the state party, but also the formation of favorable constituencies through the redistricting process). 
finance regulation. ${ }^{142}$ Nor are these distinctions simply a function of partisanship. For most election rules, significant variations occur among red and blue states, and within regions.

\section{Election Administration}

"Election Day" itself varies significantly among states. Primary campaigns kick off nearly a year before the election for March primaries in Illinois and Texas. They kick off in September, just two months before the general election primary, in Delaware, Massachusetts, New Hampshire, and Rhode Island. Louisiana holds no primary, but holds a runoff election in December if necessary. ${ }^{143}$ General election campaigns therefore can run between two and nine months, depending on the state. Two-thirds of states offer some form of early voting, beginning an average of 22 days before the election and as early as 45 days before the election. ${ }^{144}$ Twenty-two states allow early voting on weekends. ${ }^{145}$ Twenty-seven states allow "no-excuse" absentee voting by mail, and three states (Colorado, Washington, and Oregon) require voting by mail. ${ }^{146}$

Once the traditional Election Day arrives, eleven states provide same-day registration. ${ }^{147} \mathrm{~A}$ citizen is more likely to be registered to vote already in Mississippi (84\% registration) and Colorado (74\% registration) than if she lived next door in Arkansas (65\% registration) or Wyoming (64\% registration); vot-

142. See ROBERT F. BAUER, ET AL., THE PRESIDENTIAL COMM'N ON ELECTION ADMIN., THE AMERICAN VOTING EXPERIENCE: REPORT AND RECOMMENDATIONS OF THE PRESIDENTIAL COMMISSION ON ELECTION ADMINISTRATION (2014); PEW CENTER ON THE STATES, ELECTION ADMINISTRATION BY THE NUMBERS: AN ANALYSIS OF AVAILABLE DATASETS AND HOW TO USE THEM (2012).

143. 2014 Calendar: State Primary Dates and Runoff Dates, NAT'L CONF. OF STATE LEGISLATURES (Feb. 3, 2014), http://www.ncsl.org/research/elections-andcampaigns/2014-state-primary-dates-and-runoff.aspx [http://perma.cc/H9T9NUP8].

144. Absentee and Early Voting, NAT'L CONF. OF STATE LEGISLATURES (Feb. 11, 2015), http://www.ncsl.org/research/elections-and-campaigns/absentee-and-earlyvoting.aspx [http://perma.cc/X4H3-S8J2].

145. $I d$.

146. Id.

147. Same Day Voter Registration, NAT’L CONF. OF STATE LEGISLATURES (June 2, 2015), http://www.ncsl.org/research/elections-and-campaigns/same-day-registrati on.aspx [http://perma.cc/4LRL-BPM7]. 
ers need not register at all in North Dakota. ${ }^{148}$ In states where there are still polling locations, opening hour varies from as early as 5 a.m. in Vermont (6 a.m. in ten other states) to as late as 11 a.m. in neighboring New Hampshire, and closing hour varies from as early as 6 p.m. in Hawaii and Kentucky to as late as 9 p.m. in Iowa, New York, and North Dakota. ${ }^{149}$ A voter may wait to vote only a few minutes in Mississippi or New Jersey, but half an hour or longer in Florida or Maryland. ${ }^{150}$ In the 2014 election, 31 states required voter identification, ten of which had a requirement that a voter without identification take additional action after Election Day for a provisional ballot to be counted. ${ }^{151}$ Fifteen of these voter identification states required photo ID while sixteen accepted photo or non-photo IDs. ${ }^{152}$ In local and special district elections, nonresidents may vote in twelve states, and non-citizens may vote in a small but growing number of localities. ${ }^{153}$ Convicted felons can vote from prison in Maine and Vermont, but may never vote again in twelve states with permanent felon disenfranchisement where ineligible felons may make up as much as ten percent of the voting age population. ${ }^{154}$

148. U.S. CENSUS BUREAU, VOTING AND REGISTRATION IN THE ELECTION OF 2012, https://www.census.gov/hhes/www/socdemo/voting/publications/p20/2012/tables .html [http://perma.cc/3WXJ-F37K] (Table 4a, Column G); N.D. Cent. Code § 16/1010-05.1.

149. COUNCIL OF StATE GOV'TS, THE BOOK OF THE STATES 283-84 (Table 6.5) (2014), available at http://knowledgecenter.csg.org/kc/system/files/6.5\%202014.pdf [http://perma.cc/XC7Z-YQKA].

150. Charles Stewart III, 2012 Survey of the Performance of American Elections 79 (Feb. 25, 2013) (draft), available at http://hdl.handle.net/1902.1/21624 [http://perma.cc/7GKU-VRBB].

151. Voter Identification Requirements, NAT'L CONF. OF STATE LEGISLATURES (Oct. 6, 2015), http://www.ncsl.org/research/elections-and-campaigns/voter-id.aspx [http://perma.cc/UQ9K-2WHU]. The data exclude Pennsylvania's strict photo ID law, invalidated by a state court, and North Carolina's strict voter ID law, which has an implementation date of 2016 and is currently the subject of ongoing litigation.

152. Id.

153. Voting by Nonresidents and Noncitizens, NAT'L CONF. OF STATE LEGISLATURES (Feb. 27, 2015), http://www.ncsl.org/research/elections-and-campaigns/nonresident-and-non-citizen-voting.aspx [http://perma.cc/SN4H-BXN6].

154. Christopher UGgen, ET AL., THE SENTENCING PROJeCt, STATE-LEVEl EsTIMATES OF FELON DISENFRANCHISEMENT IN THE UNITED STATES, 2010, at 3-4 (2012). Including permanently disenfranchised felons, Florida may disenfranchise $10 \%$ of its voting-age population, Mississippi 8\%, and Kentucky, Tennessee, and Virginia 


\section{Constituencies and Districting}

One of the most fundamental and contested questions of representation, the choice between size of constituency and size of legislative body, is answered in a variety of ways by the States. State senates range from as large as sixty-three (New York) and sixty-seven (Minnesota) to as small as twenty (Alaska) and twenty-one (Delaware and Nevada). ${ }^{155}$ State houses and assemblies range from as large as 400 (New Hampshire) to as low as forty (Alaska), forty-one (Delaware), and forty-two (Nevada); Nebraska lacks a lower house. ${ }^{156}$ Senate constituencies range from more than 800,000 (Texas) and 900,000 (California) to less than 14,000 (North Dakota). ${ }^{157}$ House constituencies range from more than 465,000 in California to less than 10,000 in Montana, Maine, New Hampshire, Vermont, and Wyoming. ${ }^{158}$ California's average assembly constituency is the only constituency close in size to a congressional district, and more than 100 times larger than the house constituencies in New Hampshire $(3,291)$ and Vermont $(4,172) .{ }^{159}$ The smallest seven state houses and smallest five state senates today are smaller than the U.S. House and Senate, respectively, in $1789 .{ }^{160}$ Seven-

$7 \%$. Id. Another analysis excludes permanently disenfranchised felons in his estimates due to a lack of data or updated methodology. It calculates total disenfranchised felons in 2014 as high as $4 \%$ of voting-age population in Georgia, with seven other states at $2 \%$ or more: Mississippi, Alaska, Delaware, Idaho, Arkansas, Texas, and Louisiana. See Michael P. McDonald, 2014 November General Election Turnout Rates, UNITED STATES ELECTIONS PROJECT (Dec. 30, 2014), http://www.electproject.org/2014g [http://perma.cc/F5F7-2YUR] (calculating ineligible felons as a percentage of voting age population per state).

155. THE BOOK OF THE STATES, supra note 153, at 275-76 (Table 6.2), available at http://knowledgecenter.csg.org/kc/system/files/6.2\%202014.pdf

[http://perma.cc/DJE3-3DKX].

156. Id.

157. 2010 Constituents per State Legislative District Table, NAT'L CONF. OF STATE LEGISLATURES (2010), http://www.ncsl.org/research/about-state-legislatures/2010constituents-per-state-legislative-district.aspx [http://perma.cc/DFL8-3E6M].

158. $I d$.

159. Id.

160. Id. In the first Congress, the House and Senate had 65 and 26 members, respectively. See U.S. HOUSE OF REPRESENTATIVES, Congress Profiles: 1st Congress (1789-1791), http://history.house.gov/Congressional-Overview/Profiles/1st/ [http://perma.cc/9QQA-LYDZ] (last visited Nov. 14, 2015). 
teen states have house constituencies smaller than the 30,000 minimum the Constitution sets for Congress. ${ }^{161}$

All state legislators have either two- or four-year terms, ${ }^{162}$ and nearly all state executive officers have four-year terms. ${ }^{163}$ Beginning in 1990 with California, Colorado, and Oklahoma, and ending with Nebraska in 2000, twenty-two states enacted term limits on executive or legislative officials by statutory or constitutional initiative. ${ }^{164}$ Combined with pre-existing executive term limits, thirty-seven states limit the term of their governor and other executive branch officials. ${ }^{165}$ Four states invalidated term limits by state supreme court decision, and another two repealed them by legislative action. ${ }^{166}$ The wave of term limit laws represents one of the more successful recent efforts to nationalize state politics from the bottom up.

Redistricting - the state practice that may have the most direct effect on the composition of the national government-exhibits notable differences among the States. A slight majority of states leave redistricting in the control of the state legislature, although Iowa takes exceptional measures to cleanse the legislature's process of partisanship through legislative staff analysis of plans. Twenty-one states rely on some form of redistricting commission, though these commissions vary in independence. ${ }^{167}$ In thirteen states, a commission has primary authority for drawing up

161. See U.S. CONST. art. I, § 2 ("The Number of Representatives shall not exceed one for every thirty Thousand.").

162. See Number of Legislators and Length of Terms in Years, NAT'L CONF. OF STATE LEGISLATURES (Mar. 11, 2015), http://www.ncsl.org/research/about-statelegislatures/statewide-votes-on-term-limits.aspx [http://perma.cc/57SD-BJSM].

163. THE BOOK OF THE STATES, supra note 153, at 164-65 (Table 4.9), available at http://knowledgecenter.csg.org/kc/system/files/4.9\%202014.pdf [http://perma.cc/F8EK -CHHM].

164. Statewide Votes on Term Limits, NAT'L CONF. OF STATE LEGISLATURES (Mar. 25, 2015), http://www.ncsl.org/research/about-state-legislatures/statewide-voteson-term-limits.aspx [http://perma.cc/GZL8-CRYG].

165. THE BOOK OF THE STATES, supra note 153, at 164-65 (Table 4.9), available at http://knowledgecenter.csg.org/kc/system/files/4.9\%202014.pdf

[http://perma.cc/F8EK -CHHM].

166. The Term-Limited States, NAT'L CONF. OF STATE LEGISLATURES (Mar. 13, 2015), http://www.ncsl.org/research/about-state-legislatures/chart-of-term-limitsstates.aspx [http://perma.cc/PNB4-LD6S].

167. Redistricting Commissions: Legislative Plans, NAT'L CONF. OF STATE LEGISLATURES (June 27, 2015), http://www.ncsl.org/research/redistricting/2009redistricting-commissions-table.aspx [http://perma.cc/SJW3-4NXW]. 
the redistricting plan. In three states, a commission has advisory authority only. In five states, a commission serves as a backup in the event the legislature is unable to finalize a plan. Eight states form their redistricting commissions by legislative appointment, ${ }^{168}$ and eight more rely on mixed appointments by the executive branch or a combination of executive, legislative, and judicial branches or state party leaders. ${ }^{169}$ Four states form commissions from executive branch officials, and two include legislative leadership. ${ }^{170}$ One, California, uses a citizens' redistricting commission chosen by lottery. ${ }^{171}$ Most states rely on singlemember districts after a slow decline of multi-member districts in the wake of the reapportionment revolution and subsequent voting rights litigation. ${ }^{172}$ Yet, ten states continue to use multimember districts, ranging from two to eleven representatives each, in one or both houses of the state legislature. ${ }^{173}$

\section{Parties}

Party regulation provides both an opportunity for variation among states and additional opportunities for innovations by individual parties within states. Nominating conventions are permitted for major and minor parties in twenty-two states. ${ }^{174}$

168. Id. (Arizona, Connecticut, Hawaii, Illinois, Montana, New York, Pennsylvania, and Washington.).

169. Id. (Arkansas, Colorado, Missouri, Ohio, and Vermont rely on government officers. Idaho, Maine, and New Jersey rely in whole or in part on political party officers.).

170. Id. (Arkansas and Oklahoma include only executive branch officers; Mississippi and Texas add legislative leadership.).

171. Id.

172. Karl Kurtz, Declining Use of Multi-Member Districts, THE THICKET AT STATE LEGISLATURES (July 13, 2011), http://ncsl.typepad.com/the_thicket/2011/07/thedecline-in-multi-member-districts.html [http://perma.cc/MUJ9-MX5Q]; see also Josh Goodman, The Disappearance of Multi-Member Constituencies, GOVERNING THE STATES AND LOCALITIES (July 7, 2011), http://www.governing.com/blogs/ politics/The-Disappearance-of-Multi-Member-Constituencies.html [http://perma.cc/AK3F-CABU].

173. Karl Kurtz, Changes in Legislatures Using Multimember Districts after Redistricting, THE THICKET AT STATE LEGISLATURES (Sept. 11, 2012), http://ncsl.typepad.com/the_thicket/2012/09/a-slight-decline-in-legislatures-usingmultimember-districts-after-redistricting.html [http://perma.cc/8CN6-LJ4Y].

174. THE BOOK OF THE STATES, supra note 149, at 277-78 (Table 6.3), available at http://knowledgecenter.csg.org/kc/system/files/6.3\%202014.pdf [http://perma.cc/ X5N9-MLWV]. 
These conventions, which act like small-scale primaries, can serve as a testing ground for new voting methods, such as voting by mail, internet voting, and instant runoff voting. ${ }^{175}$ Eleven states hold open primaries, eleven states hold closed primaries, four states (including Nebraska's nonpartisan legislature) hold top-two primaries, and the remaining states hold some combination of primaries. ${ }^{176}$ Most states use a plurality rule, but eleven states hold runoff elections for various offices. ${ }^{177}$ Primaries exert their strongest disciplining effect in the forty-seven states that have some sort of sore loser laws; these laws spread relatively recently through the states between 1976 and 1994. ${ }^{178}$ Meanwhile, state voter registration laws and a variety of polling place affiliation processes can strengthen or weaken parties' control of membership and the extent to which the parties can effectively close their own primaries. ${ }^{179}$ As of 2014, thirty states provided for party affiliation in voter registration. Affiliations range from $51 \%$ and $65 \%$ Republican (Kansas and Wyoming, respectively) to $54 \%$ and 55\% Democrat (Kentucky and Maryland, respectively). ${ }^{180}$ Unaffiliated voters vary more widely, ranging from $8 \%$ in Kentucky to $92 \%$ in Arkansas. In the

175. The Canvass: States and Election Reform, NAT'L CONF. OF STATE LEGISLATURES (May 2011), http://www.ncsl.org/research/elections-and-campaigns/cnv-thecanvass-vol-xx-may-2011.aspx [http://perma.cc/9TUF-UMWS].

176. State Primary Election Types, NAT'L CONF. OF STATE LEGISLATURES (June 24, 2014), http://www.ncsl.org/research/elections-and-campaigns/primary-types.aspx [http://perma.cc/7LXZ-GZ7S].

177. Primary Runoffs, NAT'L CONF. OF STATE Legislatures (May 12, 2014), http://www.ncsl.org/research/elections-and-campaigns/primary-runoffs.aspx [http://perma.cc/ZM8P-NTEP].

178. Michael S. Kang, Sore Loser Laws and Democratic Contestation, 99 GEO. L.J. 1013, 1043 (2011) (arguing for "supply side" reform of political parties, including repeal of sore loser laws, to reduce polarization by increasing intraparty contestation and compromise).

179. See Renée Paradis, Party Affiliation in a System of Automatic Voter Registration, BRENNAN CTR. FOR JUSTICE (2009), http://brennan.3cdn.net/ 20f072ddef43a7d2f5_bgm6ii9s9.pdf [http://perma.cc/TW2F-T2MY].

180. Mark Blumenthal \& Ariel Edwards-Levy, HUFFPOLLSTER: A State-ByState Guide to Party Registration, HufFINGTON POST (May 27, 2014), http://www.huffingtonpost.com/2014/05/27/state-party-registration_n_ 5399977.html [http://perma.cc/C7JE-8GCC]. 
1990s, twenty states offered straight-ticket voting, but only ten do now. ${ }^{181}$

Given the Supreme Court's recognition of political parties' expressive association rights, state primary law often serves as only a default option subject to modification by individual parties. In ten states (Alaska, California, Hawaii, Idaho, Nebraska, North Dakota, Oklahoma, South Dakota, Utah, and Washington), one party chooses to operate its primary differently from how the other party operates its primary. ${ }^{182}$ Notably, in all these states but one the Republican Party opts for closed primaries while the Democratic Party opts for a more open option; only in blue Hawaii does the Democratic Party close its primary while the Republicans keep theirs open. ${ }^{183}$ These choices by party organizations, as well as legislation by the party in office, both track and shape the party dynamics within each state, with sometimes surprising divergences between the two. In one recent example, Idaho's Republican Party sued its standard-bearer Secretary of State Ben Ysursa. In the case, the Party succeeded in persuading a federal court to implement, under the First Amendment, a party closed-primary rule that its legislative supermajorities would not enact. ${ }^{184}$ A Republican legislator in neighboring Montana also sued to close that state's primaries, with the support of the state party organization but not all of the Republican state legislators. ${ }^{185}$ However, in Hawaii, a Democratic version of the Idaho strategy has so far been un-

181. Straight Ticket Voting States, NAT'L CONF. OF STATE LEGISLATURES (July 16, 2015), http://www.ncsl.org/research/elections-and-campaigns/straight-ticketvoting.aspx [http://perma.cc/LPM3-E649].

182. Congressional and Presidential Primaries: Open, Closed, Semi-Closed, and Others, CTR. FOR VOTING \& DEMOCRACY (July 2015), http://www.fairvote.org/researchand-analysis/presidential-elections/congressional-and-presidential-primariesopen-closed-semi-closed-and-top-two/ [http://perma.cc/58AS-M9AF].

183. Id.

184. See Idaho Republican Party v. Ysursa, 765 F. Supp. 2d 1266 (D. Idaho 2011). But see Greenville Cty. Republican Party Exec. Comm. v. S. Carolina, 824 F. Supp. 2d 655 (D.S.C. 2011) (rejecting state party's suit to invalidate open primary).

185. Michael Wright, Montana Republicans Divided Over Open Primaries, MONT. PUB. RADIO (Mar. 18, 2015), http://mtpr.org/post/montana-republicans-dividedover-open-primaries [http://perma.cc/KL9X-DQNG]. 
successful in voiding that state's constitutional requirement for an open primary. ${ }^{186}$

\section{Campaign Finance}

Perhaps the widest variation among state election law regimes appears in campaign finance law. Although most prominent discussions about campaign finance concern federal Super PACs and 501(c)(4) organizations, most campaign financing is conducted under state law for state elections. During the last major gubernatorial cycle in 2014, in which thirty-four of the fifty states held elections for governor, state candidates and committees (including ballot issue committees) raised $\$ 3.2$ billion - a conservative estimate that excludes some independent expenditures and electioneering. ${ }^{187}$ Despite these exclusions, and the fact that onethird of the States did not hold top-tier elections that year, the figure is still close to the nearly $\$ 3.6$ billion in contributions to the 2012 federal presidential and congressional campaigns. ${ }^{188}$ Over the most recent completed four-year cycle of 2011-2014, state campaign contributions amounted to nearly $\$ 7$ billion, ${ }^{189}$ outpacing estimated total federal campaign contributions of nearly $\$ 6.4$ billion that same cycle. ${ }^{190}$ State campaign finance and campaign finance law matter.

States are evenly split in their choices of campaign finance rules. Individual contribution limits for 2015-2016 range from approximately $\$ 50,000$ in New York to $\$ 500$ in Alaska (for governor) and $\$ 12,532$ in Ohio to $\$ 170$ in Montana (for state legislature, per election). ${ }^{191}$ Twelve states allow unlimited individual

186. See Democratic Party of Haw. v. Nago, 982 F. Supp. 2d 1166 (D. Haw. 2013), appeal pending No. 13-17545 (9th Cir. filed Dec. 13, 2013).

187. National Overview: State-Level Giving Trends (2014), FOLLOW THE MONEY, http://followthemoney.org/national-overview (last updated Mar. 14, 2016).

188. National Overview: Federal-Level Giving Trends (2012), FOLLOW THE MONEY, http://followthemoney.org/national-overview (last updated Mar. 14, 2016).

189. Contributions to candidates and committess in elections in 2014, 2013, 2012, 2011, FOLLOW THE MONEY, http://www.followthemoney.org/show-me?y=2014, 2013,2012,2011\&f-core=1 [http://perma.cc/TV29-MSJ9] (last updated Mar. 14, 2016).

190. Contributions to candidates and committees in elections in 2014,2013,2012, 2011 (within federal data), FOLLOW THE MONEY, http://followthemoney.org/show$\mathrm{me} ? \mathrm{y}=2015,2014,2013,2012 \& \mathrm{f}$-core $=1 \& \mathrm{f}-\mathrm{fc}=1$ (last updated Mar. 14, 2016).

191. State Limits on Contributions to Candidates: 2015-2016 Election Cycle, NAT'L CONF. OF STATE LEGISLATURES (May 28, 2015), http://www.ncsl.org/ 
contributions. ${ }^{192}$ Twenty-two states prohibit corporate contributions to candidates, while six allow unlimited corporate contributions. ${ }^{193}$ Five states (Iowa, Kentucky, Massachusetts, Minnesota, and West Virginia) permit union contributions while prohibiting corporate contributions, while New Hampshire prohibits union contributions while permitting corporate contributions. ${ }^{194}$ Twenty-eight states limit state party contributions to candidates, but those limits range from the same few hundred or few thousand dollars as individual limits to hundreds of thousands of dollars (per election) or more than a million dollars per cycle. ${ }^{195}$ In addition to the three fully funded campaign "clean election" states (Arizona, Connecticut, and Maine), ten other states offer other public financing programs for some or all state offices. ${ }^{196}$ Beyond these highlights, there are innumerable other distinctions in regulation of coordination rules, electioneering expenditures, attribution, and so on. In an era where many campaigns abandon the traditional political committee form, state corporate law adds a new layer of complexity to both state and federal campaigns. ${ }^{197}$

All fifty states require candidate contribution disclosure, though reporting periods range from monthly throughout an election year, weekly and daily as the election approaches (Alabama and Arkansas), to once per primary and general election (Indiana, Massachusetts, Minnesota, Mississippi, Wisconsin,

Portals/1/documents/legismgt/elect/ContributionLimitstoCandidates2015-

2016.pdf [http://perma.cc/AZQ8-9E9F].

192. Id. (Alabama, Indiana, Iowa, Mississippi, Missouri, Nebraska, North Dakota, Oregon, Pennsylvania, Texas, Utah, and Virginia).

193. Id. (Alabama, Missouri, Nebraska, Oregon, Utah, and Virginia).

194. Id. New Hampshire's corporate contribution prohibition was invalidated by a federal court in 1999. Id. In 2015, Montana amended its contribution prohibition to include unions. See An Act Generally Revising Campaign Finance Laws, $\S 4$, S.B. 289, 64th Mont. Leg. Sess. (2015).

195. State Limits on Contributions to Candidates, supra note 191.

196. State Public Financing Options: 2015-2016 Election Cycle, NAT'L CONF. OF STATE LEGISLATURES (July 17, 2015), http://www.ncsl.org/Portals/1/documents/ legismgt/elect/StatePublicFinancingOptionsChart2015.pdf [http://perma.cc/E2L7B6PE].

197. See, e.g., Michael Beckel, Why is an Obscure Montana Company One of John Kasich's Biggest Boosters?, CTR. FOR PUB. INTEGRITY (July 30, 2015), http://www.publicintegrity.org/2015/07/30/17733/why-obscure-montanacompany-one-john-kasichs-biggest-boosters [http://perma.cc/GCS3-8LSC]. 
and Wyoming), sometimes with a post-election report. ${ }^{198} \mathrm{~A}$ quarter of states do not require regular reports from political action committees. ${ }^{199}$ Most states now require some form of independent expenditure disclosure from groups other than registered political committees, with triggers ranging from zerodollar disclosure (Alaska, Georgia, New York, North Dakota, Ohio, Tennessee, and Wyoming) to $\$ 5,000$ (Arizona, Florida, and Oklahoma) and $\$ 10,000$ per four-year cycle in Maryland. ${ }^{200}$ In setting disclosure thresholds for individual contributions, many states gravitate toward the $\$ 100$ level regardless of electorate or campaign size. ${ }^{201}$ Thresholds range from "zero-dollar" disclosure of the name and address of any campaign contributor in Florida, Michigan, and New Mexico regardless of contribution amount, 202 to a $\$ 300$ contribution disclosure threshold in New Jersey and \$200 threshold in Mississippi, North Dakota, and West Virginia. ${ }^{203}$

A subtler but critical legal distinction is enforcement of campaign finance and related laws. Again, there is no dominant practice in the States, neither in terms of methodology or efficacy. Robert Huckshorn studied state campaign finance enforcement in the 1980s and concluded that, of the 26 states with election commissions at the time, there were two distinct groups: "(1) those which are empowered to enforce the law, but, for one reason or another, have an established history of limited enforcement or nonenforcement; and (2) those commissions possessing powers of enforcement which exercise them

198. State Campaign Finance Disclosure Requirements: 2015-2016 Election Cycle, NAT'L CONF. OF STATE LEGISLATURES (July 17, 2015), http://www.ncsl.org/ Portals/1/documents/legismgt/elect/StateCampaignFinanceDisclosure RequirementsChart2015.pdf [http://perma.cc/P4F9-9BZW].

199. Id.

200. Id.

201. See Independent Expenditure: Does the state require disclosure of independent expenditures?, THE CAMPAIGN DISCLOSURE LAW DATABASE, available at http://disclosure.law.ucla.edu/default.aspx [http://perma.cc/X8FV-DTKG] (last updated Dec. 31, 2006).

202. FLA. STAT. § 106.07(4)(a)(1) (2013); MiCH. COMP. LAWS §169.226(1)(e) (2013); N.M. STAT. ANN. § 1-19-31(A)(3) (2007).

203. MISS. CODE ANN. §23-15-807(d)(ii) (1999); N.J. STAT. ANN. § 19:44A-16(f) (2015); N.D. CENT. CODE § 16.1-08.1-02(2) (2013); W. VA. CODE § 3-8-5(a) (2009). 
on a regular basis." 204 Two decades later, Todd Lochner studied education, auditing, and penalty enforcement of state campaign finance agencies and still found significant variation. ${ }^{205}$ More recently, often obscure appointed state campaign practices commissions have shared the spotlight with aggressive enforcement of disclosure law by elected state attorneys general who possess broad supervisory powers over nonprofit organizations. ${ }^{206}$ Beyond law enforcement, other state officials may be responsible for-and more or less effective at-ensuring campaign finance and related reports are disclosed to the public.

\section{Other Factors}

After Election Day, many other factors interact with election law to influence the form of a state's republicanism. Are the legislators full-time or part-time? ${ }^{207}$ How often do they meet? What are their salaries? What professional staff is available? How open are meetings? How public are documents? How is lobbying defined? How is it regulated? How strict or loose are

204. Robert J. Huckshorn, Who Gave It? Who Got It?: The Enforcement of Campaign Finance Laws in the States, 47 J. POL. 773, 779 (1985).

205. Todd Lochner, Surveying the Landscape of State Campaign Finance Enforcement: A Preliminary Analysis, 4 ELECTION L. J. 329 (2005).

206. See Press Release, Cal. Dep't. of Justice, Office of the Attorney General Kamala D. Harris, Attorney General Kamala D. Harris Announces \$1 Million Civil Settlement for Campaign Finance Violations, Calls for Legislative Reform (Oct. 24, 2013), available at https://oag.ca.gov/news/press-releases/attorney-general-kamalad-harris-announces-1-million-civil-settlement-campaign [http://perma.cc/QY4F3TYX] (announcing California Attorney General's joint settlement, with the California Fair Political Practices Commission, of campaign finance disclosure prosecution); Maura Dolan, California charities must disclose major donors, court rules, L.A. TIMES (May 1, 2015), http://www.latimes.com/local/lanow/la-me-ln-charity-court20150501-story.html [http://perma.cc/CMV6-C2SN] (reporting on California Attorney General's pursuit of donor records for Center for Competitive Politics under state nonprofit law); Jonathan Stempel, Citizens United loses New York ruling over donors, REUTERS (July 27, 2015), http://www.reuters.com/article/uscitizensunited-new-york-lawsuit-idUSKCN0Q11YA20150727 [http://perma.cc/ XR3H-BP8M] (reporting on New York Attorney General's pursuit of donor records for Citizens United under state nonprofit law).

207. For example, the most-populous states tend to have full-time legislatures, but so does Alaska; the least-populous states tend to have part-time legislatures, but so do Georgia and Utah; about half of states fall in between. See Full-and PartTime Legislatures, NAT'L CONF. OF STATE LEGISLATURES (June 1, 2014), http://www.ncsl.org/research/about-state-legislatures/full-and-part-timelegislatures.aspx [http://perma.cc/VEM2-CKJG]. 
ethics laws? How does the state regulate procurement? What kind of civil service and whistleblower protections are there? Who enforces state ethics and lobbying laws? How engaged with state government are federal and state anti-corruption law enforcers? These questions are the building blocks of perennial state report cards on ethics and corruption. The inconsistency of state "grades" across reports suggests how complicated each state's political culture may be. ${ }^{208}$ For example, a recent comprehensive study of state public integrity laws ranked New Jersey and Illinois in the top ten and the Dakotas near the bottom, in part because states with a history of corruption are more likely to legislate on public integrity while in smaller states "libertarian[] roots, a small-town, neighborly approach to government and the honest belief that 'everybody knows everybody' has overridden any perceived need for strong protections in law." ${ }^{209}$ These studies necessarily reflect the subjective judgments of their authors, and only begin to capture the complexity of a state's resulting political culture.

\section{B. Rules, Regimes, and Systems of Republicanism}

There are sharp and persistent distinctions among the individual rules that structure state forms of republicanism and similarly sharp and persistent distinctions between those state rules and the rules that structure our national republicanism. By and large, the distinctions cut across big and small states, urban and rural states, and red and blue states. They represent the accretion of decades, and in some cases centuries, of consti-

208. Compare State Integrity Investigation, CTR. FOR PUB. INTEGRITY, available at http://www.publicintegrity.org/accountability/state-integrity-investigation/ [http://perma.cc/5JQR-S7TB] (last visited Nov. 17, 2015) (ranking reporters' summaries of state public-integrity laws, their efficacy, and citizen access to using those laws) with Oguzhan Dincer \& Michael Johnston, Measuring Illegal and Legal Corruption in American States: Some Results from the Corruption in America Survey, HARVARD UNIV. EDMOND J. SAFRA CTR. FOR ETHICS (Dec. 1, 2014), http://ethics.harvard.edu/blog/measuring-illegal-and-legal-corruption-americanstates-some-results-safra [http://perma.cc/Y747-2RXM] (ranking reporters' perception of illegal and legal corruption in each of the three branches of state governments).

209. Caitlin Ginley, Grading the nation: How accountable is your state?, CTR. FOR PUB. INTEGRITY (March 19, 2012), http://www.publicintegrity.org/ 2012/03/19/8423/grading-nation-how-accountable-your-state

[http://perma.cc/EH6G-YDY4]. 
tutional and statutory traditions and adaptations. While waves of national political or legal reforms sometimes introduce new rules, some states lead those reforms, some states follow, and other states resist or retrench after a time. These distinctions extend beyond just a few outlier states. Across an array of rule choices, states either spread out across the continuum of potential rules, or divide into two or three relatively evenly sized camps. Despite recent trends toward the nationalization of state politics, and accounting for the recognition of basic political equality, state republicanisms are as diverse as ever.

These distinct rules alone complicate any attempt to characterize state republicanism. Such variation has facilitated a developing political science literature about the impact of particular rules on various republican values. Any summary citation would be incomplete, though Nicholas Stephanopoulos, Eric M. McGhee, and Steven Rogers assemble many of the recent findings in their comprehensive analysis of the effect of electoral rules on representation and the other questions that arise from the study of republican pluralism in the States. ${ }^{210}$ Rule-level effects, when they exist, run in the low single-digit percentages. Yet as the discussion above suggests, the function of republicanism in the States is multivariate. Each state develops its own regime of rules to govern any particular element of election law. These regimes can produce interaction effects that aggravate or mitigate the impact of the component rules. Republican pluralism attends to the variation among state systems that cannot be explained by changes in a single rule or even a single regime.

In election administration, some states may pair early voting with strict voter identification requirements, while others limit early voting but provide a relatively convenient process at the polls. In legislative composition, states may reduce the impact of turnover from term limits with small houses that facilitate trust among members or incumbent-protective redistricting processes, while others may increase that impact with larger houses and a more competitive redistricting process. Political parties may be able to elect purer candidates in states that combine closed primaries, party affiliation in voter registration,

210. Nicholas O. Stephanopoulos, Eric M. McGhee, \& Steven Rogers, The Realities of Electoral Reform, 68 VAND. L. REV. 761, 772-77 (2015). 
plurality rules, and sore loser laws than in states that lack one or more of those rules. In campaign finance, states may concentrate fundraising on candidate campaigns by combining high candidate contribution limits with strong enforcement of independent expenditure disclosure, or divert campaign contributions into undisclosed expenditures by adopting the opposite regime. ${ }^{211}$ Public integrity factors like lobbying regulation, ethics rules, and transparency can work in combination to foster a culture of integrity, or undercut it.

At the state level, multiple regimes form a system that interacts with factors like demographics, economics, and geography to constitute a state's republican form of government. Consider, for example, the system of interactions between a state's party regulation regime and its campaign finance regime. The regimes may complement each other to increase party control of candidates in a system of closed primaries, high contribution limits for parties, and strong regulation of independent expenditures. They may also complement each other to decrease party control with open primaries, low contribution limits for parties, and unregulated independent expenditures. Some mix of regimes may produce a system that exacerbates polarization, perhaps with closed primaries and low contribution limits, but unregulated independent expenditures, or fosters moderation, perhaps with open primaries and unlimited contributions to candidates or parties that dry up independent expenditures. Neither party regulation nor campaign finance regimes alone are likely to accomplish their individual purposes without being amplified or undercut by interactions of the system.

Now, add the election administration regime to the mix. Something as simple as the election calendar can determine the amount of money a candidate may need to raise-more for a nine-month general campaign and less for a two-month general campaign. Early voting and voting by mail, on the other hand, can shorten the election calendar by weeks at its most critical stage, shifting a party's get-out-the-vote efforts while potentially mooting some campaign finance disclosure deadlines that fall after the most informed voters have cast their bal-

211. See Anthony Johnstone, The System of Campaign Finance Disclosure, 989 IoWA L. REV. BULL. 143 (2014). 
lots. Whether state or local elections are on or off the presidential cycle may determine how large or small the primary electorate is for top-tier offices and how much the general electorate will discipline potentially polarized primary choices. Add redistricting, and the system changes again. In states with legislative control of redistricting, a post-census election exerts a powerful draw for outside money as national parties seek to line up favorable districts for Congressional seats, which may impose new disciplining forces on party candidates at campaigns. The same may be true for top election officials like Secretaries of State in swing states. Add public integrity laws, and the efficacy of such outside influence might increase or decrease depending on lobbying regulations or open meeting laws. And so on.

\section{The Persistence of State Political Cultures}

States continue to exhibit distinct identities, manifest in their political cultures and linked to the institutional structure of a state rather than regional or local factors. ${ }^{212}$ A state's political culture is a function of these rules, regimes, and systems, interacting with non-legal realities like demographics, economics, and geography. State political culture is the inertia that slows onesize-fits-all reform efforts. It is the reason why changing any one

212. See Ernest A. Young, The Volk of New Jersey? State Identity, Distinctiveness, and Political Culture in the American Federal System (Duke Law Sch. Pub. Law \& Legal Series, No. 2015-11, Feb. 24, 2015), http://ssrn.com/abstract=2552866 [http://perma.cc/3FUS-6R9K] (drawing on work by Daniel Elazar, Andrew Gelman, and others to answer "yes" to the question of "whether contemporary Americans understand themselves as sufficiently attached to their state political communities for that attachment to make a difference in decisions that affect the federal structure"); Timothy Besley \& Anne Case, Political Institutions and Policy Choices: Evidence from the United States, 41 J. ECON. LIT. 7, 22 (March 2003) ("Overall, it is clear that there is interesting institutional, political, and economic variation in the U.S. states, both across space and time," and finding that political institutional variations affect political outcomes). For a contemporary example of how the persistent distinctions among state political cultures itself serves as a shield for the Union, see Ross Douthat, The Party Still Decides, N.Y. TIMES, Mar. 12, 2016, at SR9 (arguing that the provincialism of state-level politics provides a necessary check on mass democracy, by "confronting would-be demagogues with complicated ballot requirements, insisting that a potential Coriolanus or a Sulla count delegates in Guam and South Dakota, asking men who aspire to awesome power to submit to the veto of state chairmen and local newspapers, the town meeting and the caucus hall."). 
rule, no matter how radical or enlightened, barely moves the needle in transforming a state's republicanism. Across the board, a national rule, regime, or system of election law might nudge each state republicanism a little more toward participation, competition, equality, or representation on its own scale. But political culture ensures that no reform will make State A as participatory, equal, competitive, or representative as State B. Comparisons of money in politics, state voting turnout, electoral contestation, and policy alignment demonstrate the dominance of political culture in state republicanisms.

\section{Participation and Voting Turnout}

The average turnout from the voting-eligible population recently hovers around $57 \%$ in recent presidential elections and $39 \%$ in midterm elections, though this conceals a 30-point range among the states. ${ }^{213} \mathrm{~A}$ voter would be about $50 \%$ more likely to cast a vote come November in chilly Minnesota or Maine than in warmer Hawaii or Texas. ${ }^{214}$ Distinctions persist among neighboring states; Ohioans turn out more than ten percentage points more than West Virginians, and Coloradans turn out an average of fourteen percentage points more than Arizonans. ${ }^{215}$ In 2012, black voters generally voted at higher rates than white voters in the eastern third of the United States, particularly in the Mid-

213. See Michael P. McDonald, National General Election VEP Turnout Rates, 1789Present, U.S. ELECTIONS PROJECT (June 11, 2014), http://www.electproject.org/national-1789-present [http://perma.cc/3PHJ-47TB] (average national presidential and midterm turnout of voter-eligible population from 1992-2014).

214. Michael P. McDonald, State General Election Turnout Rates, 1980-2014, U.S. ELECTIONS PROJECT (2015), http://www.electproject.org/home/voter-turnout/voterturnout/data [http://perma.cc/Q2J6-QnQ2] (showing average state presidential and midterm turnout of voter-eligible population from 1992-2014). Between 1992 and 2014, Minnesota averaged 57\% in midterms (a gubernatorial year) and 74\% in presidential years; Maine averaged $54 \%$ in midterms (a gubernatorial year) and $70 \%$ in presidential years; Hawaii averaged $43 \%$ in midterms (a gubernatorial year) and $47 \%$ in presidential years; Texas (using highest office vote total instead of total ballots counted) averaged $32 \%$ in midterms (a gubernatorial year) and $51 \%$ in presidential years. $I d$.

215. Id. Between 1992 and 2014, Ohio averaged 43\% in midterms (a gubernatorial year) and $63 \%$ in presidential years; West Virginia averaged $33 \%$ in midterms and $51 \%$ in presidential years (a gubernatorial year); Colorado averaged $49 \%$ in midterms (a gubernatorial year) and 68\% in presidential years; Arizona averaged $37 \%$ in midterms (a gubernatorial year) and $52 \%$ in presidential years. Id. 
Atlantic and East South Central states, and at lower rates than white voters in the western third, particularly in the Mountain West. ${ }^{216}$ Non-Hispanic White voters generally voted at substantially higher rates than Hispanic voters, but the discrepancy was at least twenty percentage points in Central states, but less than ten points along most of the East Coast. ${ }^{217}$ Remarkably, the variation in voter turnout among states today may be greater than the historical variation in national voter turnout (among the increasing voting-eligible population) throughout the entire twentieth century. ${ }^{218}$ This interstate variation overwhelms any impact on turnout of voter ID, early voting, same-day registration, or any other single voting rule.

A second degree of variation arises beyond the biennial Tuesday after the first Monday in November. Participation in primary elections varies by a factor of two. Even in the 2008 presidential campaign for an open seat, and setting aside New Hampshire's $54 \%$ primary turnout, participation ranged from $40 \%$ or more (Oregon, Ohio, Vermont, and California) to $20 \%$ or less (Michigan, New York, Louisiana, and Republican primaries in New Mexico and Idaho), nearing the $16 \%$ participation rate for Iowa's presidential caucuses. ${ }^{219}$ This analysis considers only state and federal general elections. In local elections, turnout averages as low as $26 \%$ for city mayoral races, with turnout as much as 15 to 27 points lower for elections that do not coincide with midterm and presidential elections, respectively, than for elections that do coincide with federal elections. 220 In many urban centers, few voting rights remedies

216. THOM FILE, U.S. CENSUS BUREAU, THE DIVERSIFYING ELECTORATE-VOTING RATES BY RACE AND HISPANIC ORIGIN IN 2012 (AND OTHER RECENT ELECTIONS) 9 (2013), available at http://www.census.gov/prod/2013pubs/p20-568.pdf [http://perma.cc/4FU9-NXT4].

217. Id. at 10 .

218. McDonald, supra note 214 (between 1900 and 2014, the range of turnout was between $49 \%(1924)$ to $74 \%$ (1900) in presidential years, and $33 \%$ (1926) to $56 \%$ (1902) in midterms).

219. Michael P. McDonald, 2008 Presidential Nomination Contest Turnout Rates, U.S. ElECTIONS PROJECT (Oct. 10, 2008), http://www.electproject.org/2008p [http://perma.cc/8RC4-WFN4].

220. Thomas M. Holbrook \& Aaron C. Weinschenk, Campaigns, Mobilization, and Turnout in Mayoral Elections, 67 POL. RES. Q. 42, 51 (2014). See generally SARAH F. ANZIA, TIMING AND TURNOUT: HOW OFF-CYCLE ELECTIONS FAVOR ORGANIZED GROUPS (2014). 
would have as powerful an effect as simply moving local elections to coincide with state and federal elections.

\section{Equality and Campaign Finance}

Beyond the core of basic political equality in voting rights, the most contested arena of equality values in election law is campaign finance, and in particular the relative influence of wealthy donors on campaigns. For better or for worse, the amount of money in at-large state campaigns is comparable to federal Senate campaigns, despite the massive infusions of national campaign funding into Senate campaigns, particularly in "cheap seats" from smaller states. One study of Senate campaigns from 2010 to 2014 found the median candidate and independent spending per race to be $\$ 7$ per capita, but among the most competitive races the spending varied widely from Alaska's \$121 per voter in 2014 and Montana's \$67 per voter in 2012 to around $\$ 15$ to $\$ 17$ per voter in North Carolina (2014), Virginia (2012), Massachusetts (2012), and Colorado (2010). ${ }^{221}$ These bear a striking resemblance to the varying cost of campaigns by state found by Louise Overacker's pioneering study of campaign finance. In the 1928 presidential campaign, "[t]he cost of Democratic votes ranged from $\$ 4.46$ in Nevada [about $\$ 60$ in 2012 dollars] to nothing at all in Maine and Vermont, while the Republicans spent $\$ 1.75$ per voter in Arizona [about \$24 in 2012 dollars] and \$0.03 per voter in Maine [about $\$ 0.40$ in 2012 dollars]." 222 The median amount spent in states by each presidential campaign was about $\$ 0.50$ per voter in 1928 (about $\$ 6.70$ in 2012 dollars).223

Comparable campaign finance figures for state races are more difficult to determine. In 2014 state campaigns with governors' races, estimated per voter television campaign advertisement spending alone ranged from $\$ 10$ or more (in Rhode Island, Connecticut, and Illinois) to $\$ 2$ or less (in Vermont,

221. Grace Wallack \& John Hudak, How Much Did Your Vote Cost? Spending Per Voter in the 2014 Senate Races, BROOKINGS INST. (Nov. 7, 2014), http://www.brookings.edu/blogs/fixgov/posts/2014/11/07-spending-per-voter2014-midterm-senate-wallack-hudak [http://perma.cc/NX6b-WX4M].

222. LOUISE OVERACKER, MONEY IN ELECTIONS 77 (1932).

223. Id. at $75-76$. 
South Dakota, California, Tennessee, and Oregon). ${ }^{224}$ The mix of campaign spending changes dramatically from state to state. The dominant funding sources for television campaigns included 68\% independent expenditures in Kansas, 72\% party funds in Florida, and 100\% candidate campaign expenditures in Vermont and South Dakota (and 99\% in Texas). ${ }^{225}$ Widening the scope to all candidate fundraising, but still excluding independent expenditures, a recent study found aggregate contributions per voter of between $\$ 0.81$ and $\$ 17.75$ over the period of 2003 through 2010.226

A synthesis of both participation and equality values, participation in campaign finance varies by an order of magnitude from state to state. In the most recent gubernatorial election years on record, the top five states (Vermont in 2010, Rhode Island in 2010, Montana in 2012, Hawaii in 2010, and Massachusetts in 2010) boasted per capita campaign contribution rates of between $3.5 \%$ and $5.9 \%$ of voting age population, while the bottom five states (Florida in 2010, California in 2010, Utah in 2012 and 2010, New York in 2010, and Nevada in 2010) lagged with participation rates of just $0.2 \%$ to $0.6 \% .{ }^{227}$ The donor mix varies widely too. Large contributions (over $\$ 1000$ and PACs) account for more than $80 \%$ of candidate fundraising in Georgia, Mis-

224. Chris Zubak-Skees, State ad wars tracker, CTR. FOR PUB. INTEGRITY (May 2, 2015), http://www.publicintegrity.org/2014/09/22/15623/state-ad-wars-tracker [http://perma.cc/TBV4-QW2P].

225. Id.

226. Brian E. Adams, Determinants of Aggregate Campaign Fundraising in State Legislative Elections (APSA 2014 Annual Meeting Paper, 2014), http://ssrn.com/abstract=2455034 [http://perma.cc/GX5T-3WT7].

227. Press Release, Campaign Finance Institute, Previewing 2014: CFI Releases Analysis of Money in State Elections (Oct. 30, 2014), available at http://cfinst.org/Press/PReleases/14-10-30/CFI_Releases_Analysis_of_

Money_in_State_Elections.aspx [http://perma.cc/7LSG-ZQKB]; Press Release, Campaign Finance Institute, Vermont and Rhode Island Had the Highest Percentages of Adults Contributing in 2010 and 2006 State Elections; New York, Utah, California and Florida the Lowest (Dec. 20, 2012), available at http://cfinst.org/Press/PReleases/12-12-20/VT_and_RI_Had_the_Highest_ Percentages_of_Adults_Contributing_in_2010_and_2006_State_Elections_NY UT_CA_and_FL_the_Lowest.aspx [http://perma.cc/G5Q7-2KMF]. Excluded from these studies are two states (New Jersey and Virginia) that have post-presidential off-year gubernatorial elections (most recently in 2013), and three states (Kentucky, Louisiana, and Mississippi) that have pre-presidential off-year gubernatorial elections (most recently in 2015). 
souri, Utah, Texas, and Nevada. ${ }^{228}$ Small contributions (\$250 or less) account for the majority of funding in Connecticut and Minnesota, and more than $40 \%$ of funding in Wisconsin, Massachusetts, Rhode Island, Maine, Arizona, and Montana. ${ }^{229}$

\section{Competition and Contested Races}

Electoral competition is an elusive thing to measure, and may be even harder to promote. Looking to campaign finance data, and excluding the three "clean elections" states with full public funding (Arizona, Connecticut, and Maine), the top five most competitive states in 2011 and 2012 state legislative races (New Hampshire, Minnesota, Alaska, South Dakota, and North Dakota) had runners-up who raised at least half of the winning candidate in one-third to two-thirds of the seats. ${ }^{230}$ The eight least competitive states (Georgia, Texas, Florida, Wyoming, South Carolina, North Carolina, Oklahoma, and Missouri) had ten percent or fewer seats that rated competitive by that measure. ${ }^{231}$ Other indices comparing open seats, primary contests, and major party competition in state legislative races find similar variations in incumbency turnover, ${ }^{232}$ open seats, ${ }^{233}$ contested primaries, ${ }^{234}$ and major-party contested general elections. ${ }^{235}$

228. Previewing 2014: CFI Releases Analyses of Money in State Elections, supra note 227.

229. Id.

230. Zach Holden \& Gus Voss, Monetary Competitiveness in 2011 and 2012 State Legislative Races, NAT'L INST. ON MONEY IN STATE POlitiCS (Dec. 23, 2014), http://followthemoney.org/research/institute-reports/the-role-of-monetarycompetitiveness-in-2011-and-2012-state-legislative-races/ [http://perma.cc/63MG969U].

231. Id.

232. State Legislative Incumbent Turnover in 2014, BALLOTPEDIA, http://ballotpedia.org/State_legislative_incumbent_turnover_in_2014 [http://perma.cc/ HL25-LPJN] (last visited Nov. 14, 2015) (reporting that 2014 incumbent turnover ranged from less than $10 \%$ in Delaware, Rhode Island, Indiana, South Carolina, and Georgia to $30 \%$ or more in California, Arizona, Michigan, Montana, and Nebraska).

233. Comparing the Competitiveness Index for State Legislative Elections, BALLOTPEDIA, http://ballotpedia.org/Comparing_the_competitiveness_index_for_ state_legislative_elections [http://perma.cc/AX3T-EHC7] (last visited Nov. 14, 2015) (reporting that 2014 open seats ranged from $4 \%$ of seats in Delaware to $38 \%$ in Montana and $68 \%$ in Nebraska).

234. Id. (2014 contested primaries ranged from $2 \%$ of seats in Maine to $67 \%$ in Maryland). 


\section{Representation and Policy Alignment}

Another basic but elusive value is representation in terms of alignment between elected officials and constituents. At first glance, alignment appears to be an unimpeachable republican value, since republicanism is in, Madison's terms, simply “a government in which the scheme of representation takes place." ${ }^{236}$ But as with all republican values there are tradeoffs, and even for Madison, simple alignment in terms of majority rule is suspect. Any political community might reasonably prefer to weigh other values more heavily, such as broadbased and sustained participation in politics, equal opportunity for influence, or competition that fosters debate and refinement of policies. Representation itself takes different forms, depending on whether the relevant representation occurs at the level of the elected official, the representative body, or enacted policy. A state that places representation above all other values may have difficulty knowing how well it is achieving it.

Fortunately, political science has taken major strides in measuring and analyzing representation in terms of alignment at the state level. Consistent with distinct and persistent republican pluralism in the States, Stephanopoulos, McGhee, and Rogers find "both alignment and responsiveness vary markedly from state to state, but not very much from year to year," over a period of more than two decades. ${ }^{237}$ Legislatures in Delaware, Georgia, Idaho, and Tennessee align well with their electorates, while California and Connecticut lean to the left and those in Ohio and Michigan lean to the right. ${ }^{238}$ Of those state legislatures, however, Michigan and Tennessee are highly responsive to changes in the state electorate's preferences, Delaware is moderately responsive; California, Idaho, and Ohio are nonresponsive; and Georgia appears to move against shifts in its electorate despite its good alignment. ${ }^{239}$ Another study of

235. Id. (2014 major-party contested general elections ranged from $20 \%$ of seats in Georgia to $100 \%$ in Michigan).

236. THE FEDERALIST No. 10, at 133 (James Madison) (Benjamin F. Wright, ed., 1961).

237. Stephanopoulos, McGhee \& Rogers, supra note 210, at 765.

238. Id. at 800 .

239. Id. 
alignment of policy outcomes with state public opinion found the highest congruence in California and Louisiana (69\%) and the lowest in New Hampshire, Pennsylvania, West Virginia, and Wyoming (33\%). ${ }^{240}$

\section{THE FEDERALIST SAFEgUARDS OF POLITICS}

If the judicial, legislative, and executive branches of the federal government are unlikely to make further significant progress in guaranteeing a republican form of governmenthowever conceived - they should step aside and encourage the States to step in. National political gridlock, even if only transitional, presents an opportunity for each state to refine republicanism in response to the changing landscape of politics as each state experiences it. ${ }^{241}$ More than this, it presents an opportunity for states to play a role in breaking the national political gridlock. American federalism has been described as a series of popular movements entrusting the federal or state governments with more or less confidence as the times demand, ${ }^{242}$ and Americans now have historically low levels of confidence in the federal government. ${ }^{243}$ The means of devolution are clear enough in the federal and state constitutions, though are admittedly less clear in politics. ${ }^{244}$ The end itself is an opportunity to reconceive state republicanism and perhaps to recompose national republicanism in the diverse image of the state republics that compose the Union.

240. Jeffrey R. Lax \& Justin H. Phillips, The Democratic Deficit in the States, 56 AM. J. POL. SCI. 148, 152-53 (2012).

241. See Franita Tolson, The Union As A Safeguard Against Faction: Congressional Gridlock as State Empowerment, 88 NOTRE DAME L. REV. 2267 (2013).

242. Larry D. Kramer, Putting the Politics Back into the Political Safeguards of Federalism, 100 COLUM. L. REV. 215, 286 (2000).

243. Justin McCarthy, Confidence in U.S. Branches of Government Remains Low, GALLUP (June 15, 2015), http://www.gallup.com/poll/183605/confidence-branchesgovernment-remains-low.aspx [http://perma.cc/ATQ2-783K].

244. William Marshall recognized a political opportunity in trends that likely have accelerated since 2000. See William P. Marshall, The Last Best Chance for Campaign Finance Reform, 94 NW. U. L. REV. 335, 386 (2000) ("The unique combination of both [traditionally Republican] federalism and [traditionally Democratic] reform interests . . . could create the type of political dynamic that would make passage of [a devolution] proposal possible."). 
Whatever one's view of the current national political dysfunction, it is difficult to deny states a role in either the problem or the solution. Jack Balkin recently listed a dozen causes of intransigence and gridlock in the current national political system. ${ }^{245}$ One-third of the dozen are predominantly policies that Congress and the Supreme Court have largely left to the States (primaries, first-past-the-post elections, political gerrymandering, and state laws that discourage the exercise of voting rights by poor and minority voters). Another third were originally state policies that Congress has preempted in whole or part, or federal policies the Supreme Court invalidated in whole or part (single-member districts, campaign finance law, First Amendment restrictions on campaign finance reform and primaries, and the dismantling of preclearance under the Voting Rights Act by Shelby County v. Holder). ${ }^{246}$ Other ana-

245. Jack M. Balkin, The Last Days of Disco: Why The American Political System is Dysfunctional, 94 B.U. L. REV. 1159, 1165-66 (2014). Balkin listed:

(1) Our current system of campaign finance. (2) A primary system that leads to more ideologically extreme candidates who are unwilling (or afraid) to compromise, especially -in recent years-in the Republican Party. (3) The choice of exclusively single-member districts instead of multimember at-large districts or some version of proportional representation. (4) Relatedly, the use of first-past-the-post election rules versus runoffs or proportional representation. (5) Political gerrymandering designed either to preserve incumbency or to maximize partisan advantage (which are not the same thing). (6) State electoral laws and practices designed to restrict or discourage the exercise of voting rights by poor people and minorities. (7) The decision in Shelby County v. Holder, which crippled the preclearance provisions of the Voting Rights Act. (8) First Amendment doctrines that limit campaign finance reform or prevent reform of the primary system. (9) The organization of House and Senate committees, which prevent legislation from moving forward. (10) The elimination of earmarks in appropriations bills, which limits the scope of potential bargains with individual Congressmen and Senators. (11) Senate rules involving filibusters, holds, and requirements of unanimous consent, which have been recently modified or eliminated for executive and some judicial appointments, but which still delay much legislation. (12) The so-called Hastert Rule, under which the Speaker of the House will refuse to allow a vote on legislation supported by a majority of the House unless a majority of his caucus also supports it.

Id.; see also Yasmin Dawood, Democratic Dysfunction and Constitutional Design, 94 B.U. L. REV. 913 (2014) (arguing that dysfunction arises from too many constraints on government action under a presidential system).

246. The remaining third are Congressional rules or conventions that states have no direct role in perpetuating, namely Congressional committee organization, 
lysts reach similar diagnoses based on similar symptoms, most of which occur at the state level. ${ }^{247} \mathrm{~A}$ republican perfectionist, taking a national perspective, might view the first set of problems as failures of the federal government to act and the second set of problems as federal mistakes to be corrected by a future federal regime. A republican pluralist, taking a state perspective, might see both sets of problems as opportunities for state innovation even where (as in the second set) contested republican perfectionism at the national level has limited the possibilities for reform.

In either case, as long as the federal government is unable to break the gridlock, the States are where the action is. Even if "the federal government-especially its courts-plays a more significant role today," which Tokaji and Wolfe endorse, "election administration is still mostly a matter of state law and local practice." 248 State laws also structure parties and representation through primaries and redistricting, with significant consequences for national politics, and there is no immediate prospect of changing that. ${ }^{249}$ Although these spheres of state political autonomy are coming under increasing pressure from national expenditures in state campaigns - in part to gain national political control over the crucial state levers of election administration

elimination of earmarks, filibuster and related hold-up rules, and the Hastert Rule.

247. See CAIN, supra note 51 (urging reforms including equality in election administration, party-building reforms to campaign finance, more selective disclosure laws, limits to the number and duration of elections, moderated direct democracy, and increased campaign finance participation through public funding); Pildes, supra note 47 (defragmenting political parties through campaign finance reform, presumably at the state and federal level, to channel money toward party leaders); Schleicher, supra note 31 (suggesting state electoral reform to mitigate the problem of "second-order" voting for state officials based on preferences about federal politics, increase the autonomy of state politics, and improve the functioning of federalism).

248. Tokaji \& Wolfe, supra note 100 , at $970-71$.

249. See Pildes, supra note 108 , at $298-319$. See also Raymond La Raja \& Jonathan Rauch, The state of state parties - and how strengthening them can improve our politics, BROOKINGS INST. (2016) ("Historically, and still today, state parties act as a counterforce against highly motivated, ideologically extreme minorities of the sort that are polarizing and fragmenting American politics. Today, however, state party organizations are falling behind, partly because the nature of politics has changed but partly, also, because of disadvantages imposed on them by well-meaning laws and policies."). 
and redistricting-state law still sets the ground rules. Most campaign finance runs through the States. Nearly all election administration policy comes from the States. Nearly all elected offices, constituencies, and representative bodies are in the States. Nearly all redistricting and party regulation occurs at the state level. In most of these policy areas, there is greater diversity among election laws in the States today than has existed across changes at the federal level over the past century.

State politics demonstrate the same diversity relative to national politics for many practices, including participation in turnout terms, competitiveness in contestation terms, and equality in campaign finance terms. As the Supreme Court recognized in assessing the line between state and federal qualifications for state officials in Gregory v. Ashcroft, 250 the realm of republicanism itself is an important place for federalism to play out. "It assures a decentralized government that will be more sensitive to the diverse needs of a heterogeneous society; it increases opportunity for citizen involvement in democratic processes; it allows for more innovation and experimentation in government; and it makes government more responsive by putting the States in competition for a mobile citizenry." 251 States have been, and will continue to be, laboratories of democracy in the term's most literal sense..$^{252}$

\footnotetext{
250. 501 U.S. 452 (1991).

251. Id. at 458 .

252. See New State Ice Co. v. Liebmann, 285 U.S. 262, 311 (1932) (Brandeis, J., dissenting). Beyond the basic inherent value of states' autonomy in developing their republican forms of government, William Marshall provides five reasons state campaign finance laws might be superior to federal campaign finance laws: (1) mitigating entrenchment, (2) ameliorating unintended consequences, (3) integrating other election laws, (4) increasing citizen participation, and (5) facilitating policy experimentation. See William Marshall, The Constitutionality of Campaign Finance Regulation: Should Differences in a State's Political History and Culture Matter?, 74 MONT. L. REV. 79, 91-92 (2013). Each of these might be extended beyond campaign finance to election administration, districting and representation, and party regulation. These reasons are variations on the standard arguments for decentralization under federalism, a classic statement of which is Michael McConnell, Federalism: Evaluating the Founders' Design, 54 U. CHI. L. REV. 1484, 1493 (1987) ("Three important advantages of decentralized decision making emerge from an examination of the founders' arguments and the modern literature. First, decentralized decision making is better able to reflect the diversity of interests and preferences of individuals in different parts of the nation. Second, allocation of decision making authority to a level of government no larger than
} 
States are especially suited to experiment in the area of democracy itself. For all the work political theory does in election law doctrine, a lot of election law is contested on empirical grounds or otherwise turns on the effect a particular republican regime has on the public. Bruce Cain notes: "the thresholds for change at the state and local level are less, and that is where institutional experimentation should occur." 253 For example, as Richard Hasen argues, the regulation of false campaign speech may call for narrower laws or new institutions to facilitate counterspeech; ${ }^{254}$ yet the efficacy of such solutions cannot be known without some experimentation and evaluation at the state level. When states enjoy greater freedom to diversify their regimes, they may help resolve intramural debates and perhaps unify reform agendas. Which primary systems minimize polarization? Which districting standards maximize minority policymaking power? Which campaign finance systems minimize the appearance of corruption? Which election reforms maximize voter turnout? Some or all of these questions may have a right national answer at some point, but nationalization of the issue by Congress or the Supreme Court may not be the best way to get there. ${ }^{255}$ While proposed Congressional reforms gather dust, some 32 states enacted 94 bills on campaign finance issues alone in 2015. ${ }^{256}$

In 2000, William Marshall warned of the high stakes involved in the continued nationalization of election law, with a focus on campaign finance. "[W]hen the barriers to success are so high, and the risks of miscalculation so great," he argued, "the regulatory reform of first resort should be the states and not the federal

necessary will prevent mutually disadvantageous attempts by communities to take advantage of their neighbors. And third, decentralization allows for innovation and competition in government.").

253. CAIN, supra note 51, at 214.

254. Richard L. Hasen, A Constitutional Right to Lie in Campaigns and Elections?, 74 MONT. L. REV. 53 (2013).

255. See, e.g., HEATHER K. GERKEN, THE DEMOCRACY INDEX: WHY OUR ELECTION SYSTEM Is FAILING AND HOW TO FIX IT (2009) (proposing rankings of state and local election administration to facilitate experimentation and accountability through democratic processes).

256. Campaign Finance Legislation Database: 2015 Onward, NAT'L CONF. OF STATE LEGISLATURES (July 2, 2015), http://www.ncsl.org/research/elections-andcampaigns/campaign-finance-database-2015-onward.aspx [http://perma.cc/AQZ26JG4]. 
government." 257 Similarly, Hasen warns against broad constitutional changes to remedy what may be a transitional period of dysfunction. ${ }^{258}$ After sweeping campaign finance reforms of BCRA led to Citizens United and Super PACs, after the principle of meticulous electoral equality in Bush $v$. Gore led to very little, ${ }^{259}$ and after the current presidential administration's reenergized voting rights enforcement was followed by the hobbling of $\S 5$ of the Voting Rights Act, ${ }^{260}$ caution may call for a lowerstakes approach rather than another risky one-size-fits-all solution. More than a decade ago, Heather Gerken diagnosed what she called a "doctrinal interregnum," and suggested the importance of the courts enabling other institutional actors into "a more dynamic process for resolving these problems than the command-and-control strategy deployed by the courts thus far." ${ }^{261}$ Bold federal efforts by Congress, the President, and the Supreme Court, often in incoherent combination, have both exacerbated the flaws of our national republicanism and entrenched them in a three-branch stalemate. It is as urgent as ever that election law somehow find a way to move on.

\section{A. State Means}

Recall the national Constitution leaves ample space for the development of republican pluralism consistent with established standards of basic political equality. Nothing prevents states from structuring their own elections, ${ }^{262}$ so long as they do not deny or abridge the right to vote on account of race, ${ }^{263}$ sex, ${ }^{264}$ taxes, ${ }^{265}$ or age (if eighteen or older), ${ }^{266}$ or violate appro-

257. Marshall, supra note 244, at 336.

258. Richard L. Hasen, Political Dysfunction and Constitutional Change, 61 DRAKE L. REV. 989, 1013-20 (2013).

259. See Justice John Paul Stevens, Bush v. Gore and the Equal Protection Clause, Address at the American Law Institute 89th Annual Meeting, at 9 (May 21, 2012), available at http://www.supremecourt.gov/public/info/speeches/ ALI\%20Speech.pdf [http://perma.cc/M5NW-KGJF] (arguing for heightened scrutiny for partisan gerrymanders under the Equal Protection Clause).

260. See Shelby Cty. v. Holder, 133 S. Ct. 2612 (2013).

261. Heather Gerken, Lost in the Political Thicket: The Court, Election Law, and the Doctrinal Interregnum, 153 U. PA. L. REV. 503, 539 (2004).

262. See generally Marshall, supra note 244, at 376-91.

263. U.S. CONST. amend. XV.

264. U.S. CONST. amend. XIX.

265. U.S. CONST. amend. XXIV. 
priate legislation enforcing these and other rights. ${ }^{267}$ Except for its guarantee of a "Republican Form of Government," 268 the original Constitution says little about state elections beyond repeated implications that the States will have legislatures and some form of executive and judicial officers. ${ }^{269}$ As to federal elections, the Constitution provides states the power to prescribe "[t]he Times, Places and Manner of holding Elections for Senators and Representatives," 270 subject to alteration by Congress. States also have the power to direct the manner, though not the time, of appointment for presidential electors. ${ }^{271}$

Under this constitutional structure it has taken multiple affirmative decisions by Congress, the Supreme Court, or both, to nationalize state politics to its current extent. These decisions are most clear in the preemption of "any provision of State law with respect to election to Federal office" in the Federal Election Campaign Act. ${ }^{272}$ Notably, in an era of increasingly strict constructions of Congress's powers, this arguably exceeds the original understanding of the Elections Clause, which was ratified only in light of serious entrenchment concerns that militate against Congress writing its own campaign finance rules. ${ }^{273}$ This same trend narrowed federal power under the Voting Rights Act over voting rights and related redistricting and election administration. ${ }^{274}$ So it is possible that any move by Congress to devolve republicanism might also involve a nudge by the Supreme Court. But the Court itself also remains an important obstacle to

266. U.S. CONST. amend. XXVI.

267. See, e.g., U.S. CONST. amend. XIV, § 5 .

268. U.S. CONST. art. IV, $\S 4$.

269. See, e.g., U.S. CONST. art. VI, cl. 3 ("The Senators and Representatives before mentioned, and the Members of the several State Legislatures, and all executive and judicial Officers, both of the United States and of the several States, shall be bound by Oath or Affirmation, to support this Constitution.").

270. U.S. CONST. art. I, § 4, cl. 1; see also U.S. CONST. amend. XVII (providing for direct election of Senators).

271. U.S. CONST. art. II, § 1, cl. 2.

272. 52 U.S.C. $\$ 30143($ a) (2014).

273. See Robert G. Natelson, The Original Scope of the Congressional Power to Regulate Elections, 13 U. PA. J. CONST. L. 1, 46 (2010) ("The power of Congress to regulate its own elections is a power that, while necessary to address unusual situations, nevertheless invites self-dealing and abuse. In cases of doubt, it must be narrowly construed.").

274. See Shelby Cty. v. Holder, 133 S. Ct. 2612 (2013). 
devolution, particularly given its increased scrutiny of state election law relative even to federal election law, ${ }^{275}$ especially when such scrutiny is unjustified and may be counterproductive. ${ }^{276}$

States retain some room to maneuver despite the Court's incoherent approach to republicanism. Even in the area of campaign finance, several Justices have indicated a recognition of the drawbacks of nationalizing state politics, and at times when writing on their own, they have expressed a willingness to allow the States more latitude in determining their republican forms of government. Dissenting in McIntyre v. Ohio Elections Commission, 277 Justice Scalia criticized the majority for "set[ting] their own views - on a practical matter that bears closely upon the real-life experience of elected politicians and not upon that of unelected judges - up against the views of 49 (and perhaps all 50 ... ) state legislatures and the Federal Congress." ${ }^{278}$ Concurring in Nixon v. Shrink Missouri Government PAC, ${ }^{279}$ Justice Breyer explained, "Where a legislature has significantly greater institutional expertise, as, for example, in the field of election regulation, the Court in practice defers to empirical legislative judgments - at least where that deference does not risk such constitutional evils as, say, permitting incumbents to insulate themselves from effective electoral challenge." 280 Dissenting in Nixon, Justice Kennedy said he would prefer to "free Congress or state legislatures to attempt some new reform, if, based upon their own considered view of the First Amendment, it is possible to do so." $281 \mathrm{He}$ might have added as a factor the

275. See Adam Winkler, Fatal in Theory and Strict in Fact: An Empirical Analysis of Strict Scrutiny in the Federal Courts, 59 VAND. L. REV. 793, 857 (2006) ("In campaign speech cases, where the survival rate was only 24 percent, all of the federal campaign speech laws adjudicated under strict scrutiny were upheld and only a minority of state laws survived."); see also Pildes, supra note 99, at 47 ("The federal courts are less deferential to state judicial interpretations of state election laws, even in state elections, than the federal courts are in other areas."). But see Douglas, supra note 138.

276. See supra Part II.A.

277. 514 U.S. 334 (1995).

278. Id. at 381 (Scalia, J., dissenting).

279. 528 U.S. 377 (2000).

280. Id. at 402 (Breyer, J., concurring).

281. Id. at 409-10 (Kennedy, J., dissenting); see also Randall v. Sorrell, 548 U.S. 230, 264-65 (2006) (Kennedy, J., concurring in the judgment) ("The universe of campaign finance regulation is one this Court has in part created and in part per- 
State's own considered view of another crucial constitutional provision: the republican form of government.

Of equal importance, state constitutions provide ample means of regulating both state and federal elections that are superior to Congress's own powers. Many state constitutions guarantee an express right to vote, and some provide "free and open" elections. ${ }^{282}$ Several common state constitutional features increase accountability and reduce the risk of entrenchment. Twenty-seven states have some form of statutory initiative or referendum by citizen petition. ${ }^{283}$ Initiatives, or threats of initiatives, play at least a modest role in electoral reforms, particularly those opposed by incumbent officials. ${ }^{284}$ While it is a doubleedged sword of accountability and anti-entrenchment, most states hold elections for judges on their courts of last resort. ${ }^{285}$ This increased legislative responsiveness to each state's citizens facilitates diverse state constitutional and statutory election regimes driven by each state's "political traditions, structures, and exigencies," 286 and is therefore likely to be more effective than nationalization at perfecting any particular conception of republicanism. More broadly, such an innovative reform as the "separation of electoral powers" Edward Foley has proposed, ${ }^{287}$

mitted by its course of decisions. That new order may cause more problems than it solves.").

282. See generally Joshua A. Douglas, The Right to Vote Under State Constitutions, 67 VAND. L. REV. 89, 101-04 (2014).

283. THE BOOK OF THE STATES, supra note 149, at 352-53 (Table 6.9), available at http://knowledgecenter.csg.org/kc/system/files/Chapter_6.9.pdf [http://perma.cc/6NYM-FCCC].

284. See Nathaniel Persily \& Melissa Cully Anderson, Regulating Democracy Through Democracy: The Use of Direct Legislation in Election Law Reform, 78 S. CAL. L. REV. 997, 1034 (2005).

285. THE BOOK OF THE STATES, supra note 149, at 307-09 (Table 5.6), available at http://knowledgecenter.csg.org//kc/system/files/Table_5.6.pdf

[http://perma.cc/S955-3CEH]. Thirty-eight states hold retention elections; twentyone states select justices by election. Id. For example, it is hard to imagine any unelected federal judge offering as detailed a critique of Citizens United as the Montana Supreme Court's populist decision and dissent in W. Tradition P'ship v. Atty. Gen., 271 P.3d 1 (Mont. 2011), rev'd sub nom. Am. Tradition P'ship v. Bullock, 132 S. Ct. 2490 (2012).

286. Marshall, supra note 244 , at 383.

287. See Foley, supra note 127. It is worth noting that more aggressive interpretations of the Guarantee Clause might deny states either the means or the ends necessary for such an effort toward perfecting republicanism. See, e.g., Berg, supra note 59, at 242 (arguing state delegation of certain powers violates the republican 
is inconceivable at any but the state level, where novel allocations of judicial, legislative, and executive powers are possible under flexible state constitutions.

While these features of state politics compare favorably to the federal status quo, it is possible to overstate their relative benefits. Although in theory it is more difficult for any particular faction to coordinate entrenchment in fifty state legislatures than in one Congress, state-oriented national campaign and lobbying groups may exploit the relatively low cost of election or access to state legislatures where its national principals might achieve relatively high policy payoffs from coordinated state action. 288 The question is whether federal or state efforts are more likely to counter these nationalizing trends. Effective regulations for such campaign and lobbying groups may be more likely to come from locally responsive and institutionally diverse state offices than from the FEC, IRS, or other federal agencies with at best indirect jurisdiction over (and indirect interest in) such groups.

Even if, despite the States' structural defenses, entrenchment in the States were more of a problem than entrenchment in Congress, this does not argue for continued nationalization. It is a fallacy of composition to conclude that the effect of increased state entrenchment on federal elections is necessarily increased entrenchment in federal offices. ${ }^{289}$ For example, any one state legislature may well manipulate campaign finance, the primary process, voter identification requirements, or the Electoral College. Several analysts find "[p]artisan manipulation of election laws in an effort to help one's own party win" may be on the rise. ${ }^{290}$ But across all

guarantee); Heller, supra note 34, at 1759-60 (arguing that constitutional initiatives that may not be modified by the legislature violate the republican guarantee).

288. See Patrick M. Garry et al., Raising The Question Of Whether Out-Of-State Political Contributions May Affect A Small State's Political Autonomy: A Case Study Of The South Dakota Voter Referendum On Abortion, 55 S.D. L. REV. 35, 46 (2010); Mike McIntyre, Conservative Nonprofit Acts as a Stealth Business Lobbyist, N.Y. TIMES (April 21, 2012), http://www.nytimes.com/2012/04/22/us/alec-a-tax-exempt-groupmixes-legislators-and-lobbyists.html?_r=4\&hp [http://perma.cc/DJ6K-4YVC] (describing the American Legislative Exchange Council (ALEC) state-oriented lobby).

289. See generally Adrian Vermeule, Foreword: System Effects and the Constitution, 123 HARV. L. REV. 4, 7 (2009) ("[M]ultiple failures of the ideal can offset one another, producing a closer approximation to the ideal at the level of the overall system.").

290. Foley, supra note 127, at 141; see also Dawood, supra note 138; Joshua A. Douglas, supra note 138, at 594 . 
fifty states, entrenchment effects can offset each other as the mixture of different election law regimes produces a more diverse Congress and Presidential Electors that could not be attributable (as it may be now) to a single entrenched federal regime.

Madison, of course, foresaw how national republicanism properly conceived still may allow " $t]$ he influence of factious leaders [to] kindle a flame within their particular States." 291 But so long as states remain under the broad shield of the republican guarantee, they "will be unable to spread a general conflagration through the other States." 292 The same diversity of policies at the state level also ameliorates unintended consequences by internalizing most of the costs of a dysfunctional policy and limiting the rest of the costs to the impact of one state among fifty. Such risks of factious or partisan conflagration have been reduced over time with the additional federal constitutional guarantees of basic political equality, and the various state constitutional innovations to circumvent self-interested officials discussed above.

In the worst-case scenario, a state's entrenched regime is still more likely than an entrenched federal regime to align with its citizens' distinct republican values. A state's citizens bear responsibility for the quality of their republican form of government, which, by definition, is a government its citizens can control. States may not only better internalize their policies, but also better integrate their policies. National policies, on the other hand, can blunder on their merits as well as in their interaction with state policies. As William Marshall argues:

Allowing states to adjust their campaign finance rules to reflect such [local] realities would both assist the states in enacting legislation that corresponds to their other laws governing elections and perhaps encourage the states to more thoroughly analyze proposed election laws through the lens of its effects on campaign funding issues. ${ }^{293}$

Both of these interests hold as true for an overly strict or liberal campaign finance regime as they do for election admin-

291. THE Federalist No. 10, at 136 (James Madison) (Benjamin Wright ed., 1961).

292. Id.

293. Marshall, supra note 139, at 92. 
istration, redistricting, and primary systems, as well as for their potential interactions.

Finally, any proposal that urges the Supreme Court or Congress to "correct" or perfect state republicanism must account for the endogeneity of those institutions to the political system the states help structure. As Eric Posner and Adrian Vermeule explain, "[j]udges are inside the political system, not outside it," 294 and any dominant party in Congress that enjoys the political unity to advance major changes to the political process "will have the least interest in enacting them." ${ }^{295}$ It is not clear that a deeply divided Supreme Court or Congress that is, in part, a product of deeply divided federal political processes (as well as earlier federal judicial and legislative regulation and deregulation of political processes) will be any better positioned to rise above entrenched dysfunction than the States. In countering such dysfunction, it may be more effective to recognize and work through the States' central role in any process of reforming national republicanism.

\section{B. Republican Ends}

Devolution of the reform of republicanism to the States might result in deep structural reforms to campaigns and elections, perpetuation of the status quo, or deregulation. Whatever the result, it is more likely to be internally coherent within each state, flexible, and reflective of citizens' specific concep-

294. Eric A. Posner \& Adrian Vermeule, Inside or Outside the System?, 80 U. CHI. L. REV. 1743, 1757 (2013). A recent confirmation of the judiciary's situation within politics, as well as the dysfunction between the other two branches, is the Senate's unprecedented refusal to consider an elected President's Supreme Court nominee until after the President's successor is elected. See Robin Bradley Kar \& Jason Mazzone, Why President Obama Has the Constitutional Power to Appoint-and Not Just Nominate-a Replacement for Justice Scalia (Mar. 21, 2016), http://ssrn.com/abstract=2752287 [http://perma.cc/82GG-B4M2]. Another such confirmation, with direct application to questions of republican pluralism, is the commitment of both candidates for the Democratic presidential nomination "to use opposition to Citizens United as a litmus test for Supreme Court nominees." Matea Gold \& Anne Gearan, Hillary Clinton's litmus test for Supreme Court nominees: a pledge to overturn Citizens United, WASH. POST (May 14, 2015), http://www.washingtonpost.com/news/post-politics/wp/2015/05/14/hillaryclintons-litmus-test-for-supreme-court-nominees-a-pledge-to-overturn-citizensunited/ [http://perma.cc/TS8W-3MGR].

295. Posner \& Vermeule, supra note 294, at 1759. 
tions of a republican form of government than the current patchwork of uneven judicial doctrine, regulation, and enforcement accumulated through attempts to nationalize state politics. Each state has its own political culture, reflected in the distinctions discussed above. As William Marshall puts it, "[S]ome of the differences in political culture between the states may express very different views of democratic theory .... [I]ndeed, each state appears to express its own theory of democracy." 296 In addition to holding distinct values, the States also generate vastly different political dynamics driven by things like media markets and the size of legislative districts. ${ }^{297}$ Bruce Cain observes in arguing for a "metapluralist" approach to reform pluralism that "[c]onsistency of any one approach is not possible." 298 It takes different means, and perhaps different ends, to govern different political systems.

Beyond each state's republicanism, however, republican pluralism among the States also may be the last best chance for reforming national republicanism. Some reformers favor devolution to the states for its own sake. For them, the best approach would extend republican pluralism closer to the outer limits of the republican guarantee consistent with weak enforcement of basic political equality. These pure pluralists would roll back relatively modest federal efforts to fund and regulate state and local election administration. They might celebrate the hobbling of the Voting Rights Act and limit its remaining enforcement to "first generation" barriers to voting itself, supplemented by Fourteenth and Fifteenth Amendment prohibitions on discrimination. They would step back from national debates over Congressional gerrymandering and perhaps even repeal the federal single-member restriction on Congressional districts. ${ }^{299}$ They would oppose further judicial regulation of state primary processes. And they would be as critical of the current Supreme Court's campaign finance doctrine as they are supportive of its voting rights decisions, though they would cheer challenges to BCRA's regulation of

296. Marshall, supra note 139 , at 86.

297. See id. at 82-83.

298. CAIN, supra note 51, at 195 (emphasis omitted).

299. See 2 U.S.C. § 2(c) (2012). 
state parties. ${ }^{300}$ Perhaps, they hope, Congress will repeal or the Supreme Court will invalidate federal preemption of state campaign finance regulation of federal campaigns. ${ }^{301}$ The States would take it from there.

Other reformers should consider embracing republican pluralism to achieve non-pluralist ends, however. Republican pluralism is a fact, and contested republican values like accountability and participation, majority rule and minority representation, deliberation and responsiveness, equality and liberty of influence, legitimacy and self-expression, competition and stability may conflict inherently or in implementation. But even perfectionist reformers who believe in any one of these values may find more success in realizing it nationally by developing it in the States. They should embrace pluralism as a source of innovation, and make a virtue out of the necessary premise that states vary widely in their republican forms of government. Reform of the national government is impossible without working through the States, even for one-size-fits-all solutions. There is no way past national political dysfunction but through it, and cultivating pluralism in the states may provide a more effective means toward national perfectionist ends.

\section{Competition}

Some of the most important factors of political competition are already controlled by the States. The States can be particularly effective agents of anti-entrenchment for federal officials because state, rather than federal, officials make the rules. Across the range of election laws, it is more difficult to capture fifty state legislatures than it is to capture Congress. In election administration, this difference has made further progress on uniform registration, early voting, and voter identification difficult beyond reforms of the past two decades, but it also has prevented uniform retrenchment on these fronts. Election administration may be excessively partisan toward one party in some states, but at least it is not uniformly partisan toward a single party across all states.

300. See, e.g., Complaint at 1, Republican Party of La. v. Fed. Election Comm'n, No. 15-cv-01241-CRC (D.D.C. Aug. 3, 2015).

301. See 52 U.S.C. § 30143(a) (2014). 
Similarly, despite the high national political stakes, many states have begun to innovate politically independent redistricting processes; there is no guarantee that a national nudge toward redistricting reform from an already deeply gerrymandered Congress would be in the direction of reform rather than retrenchment. States' roles in party regulation, particularly through the primary system, also have more potential to counteract polarization by reflecting and preserving distinct state party values. Finally, states also might fix the federal campaign finance system, for their own Congressional delegations and in their own ways, if Congress would only let them.

\section{Equality}

Equality often involves a clear tradeoff with other values, such as liberty. This is all the more reason to leave the expression of such values primarily to the States. Assuming a national reformer wished to increase political equality beyond the basic political equality established by the Constitution, particularly in terms of preventing corruption and equalizing the access and influence enjoyed mainly by wealthy interest groups over Congress (as well as state officials), states provide a novel approach to a fraught issue. With minor exceptions, ${ }^{302}$ federal campaign finance law sets one-size-fits-all rules regardless of a candidate's constituency. Federal individual contribution limits for 2016 are \$2,700 to federal candidates, and federal contribution disclosure is triggered at $\$ 200$, regardless of whether that candidate's constituency is the United States or Wyoming's one at-large congressional district (which is more than 500 times smaller in population). ${ }^{303}$ Federal regulation of coordination and electioneering expenditures is complex to the point of inefficacy and is underenforced.

If campaign finance regulation of federal candidates were returned to the States, these thresholds could reflect each state's balance of anti-corruption and (within the bounds established by

302. Federally coordinated party expenditure limits vary depending on the voting-age population of each state. See 52 U.S.C. § 30116 (2014).

303. See FED. ELECTION COMM'N, CONTRIBUTION LIMITS FOR 2015-2016 FEDERAL ELECTIONS (2015), http://www.fec.gov/info/contriblimitschart1516.pdf [http://perma.cc/6YUT-DYYK]; 52 U.S.C. §30116(a)(1)(A) (2012); 52 U.S.C. $\S 30104(b)(3)(A)(2012)$. 
the anti-corruption interest) equality interests. ${ }^{304}$ States may increase the candidate contribution limits to check the influence of Super PACs funded by the super-wealthy (even at the expense of increasing contributions by the moderately wealthy), or reduce disclosure requirements to invite larger anonymous contributions by publicity-shy donors who might otherwise give nominal amounts. Other states may reduce the contribution maximums and disclosure thresholds, reflecting lesser campaign costs or greater concerns about corruption. A few states might extend public financing to Congressional elections. Some states may deregulate campaign finance for their federal elections altogether. And any state might enforce its laws more effectively than the FEC currently enforces federal law.

\section{Representation}

Multiple state rules bear on the quality of representation federal elections can provide, at least in terms of federal officials' policy alignment with their state-based constituencies. A state's redistricting process will shape a federal candidate's electorate directly. The state election calendar and party regulation, interacting in the primary process, also will impact whether a candidate is elected with a broader or narrower base of support. State-specific campaign finance rules may determine whether a candidate can rely on larger individual or political committee contributions within the district to fund most of a campaign, or must depend on support from national Super PACs or activist out-of-state donors.

The remarkable variation in representational alignment among states raises basic questions about how reformers might improve representation at the state and federal levels, given the array of electoral rules, regimes, and systems states control. Stephanopoulos, McGhee, and Rogers cite sore loser laws, early voting, contribution limits, and independent redistricting commissions as increasing alignment, and public financing, term limits, and open primaries as possibly reducing alignment. ${ }^{305}$ Within any one state seeking to maximize alignment, nearly all

304. See generally Anthony Johnstone, Recalibrating Campaign Finance Law, 32 YALE L. \& POL'Y REV. 217 (2013).

305. See Stephanopoulos, McGhee \& Rogers, supra note 210, at 829-30. 
of these reforms could apply to federal elections, except for term limits (which may compromise alignment) and campaign finance reforms (unless federal preemption is repealed).

\section{Participation}

Participation provides one of the clearest opportunities for progress in the States, given the wide range of voter turnout and campaign finance participation. National reforms to voter registration have fallen short, and other national reforms like BCRA's regulation of state party get-out-the-vote efforts run counter to efforts at increasing participation. State turnout is a complicated function of each state's political culture and legal system, which itself arises from interactions among election administration, districting, party regulation, and campaign finance regimes. Within a state's election administration regime, different tradeoffs between early voting and polling hours, or voter ID requirements and mail voting opportunities, could produce distinct participation outcomes depending on interactions with other rules and regimes, as well as demographics and geography. Early and mail voting may increase turnout in some states but enable procrastination in others that would benefit more from more convenient polling places or hours. States that already provide ample voting opportunities might concentrate instead on increasing political competition through redistricting or campaign finance. The mix will be different for each state and will always be constrained by limited resources. But the logic of republican pluralism suggests that any fixed set of financial and political resources dedicated to increasing participation (or pursuing other values) will result in a greater payoff when working within a state's distinct republicanism.

Full participation includes citizen participation in forming and reforming the rules that govern their republic. ${ }^{306}$ This may be especially important for campaign finance given the extremely narrow section of Americans that donate. ${ }^{307}$ Increased

306. See Marshall, supra note 139, at 92-93.

307. See Lee Drutman, The Political 1\% of the 1\% in 2012, SUNLIGHT FOUNDATION BLOG (June 24, 2013), http://sunlightfoundation.com/blog/2013/06/24/1pct_of_ the_1pct/ [http://perma.cc/AK4Z-VE53] ("More than a quarter of the nearly $\$ \overline{6}$ billion in contributions from identifiable sources in the last federal campaign cycle 
participation itself helps perfect the republican form of government, of which Madison deemed essential "that it be derived from the great body of the society, not from an inconsiderable proportion, or a favored class of it." 308 Spencer Overton, articulating a modern variation of what he calls "the Participation Interest," explains that "[p]articipation exposes the electorate to a variety of ideas and viewpoints, furthers selfgovernment, and enhances the legitimacy of government decisions." ${ }^{309}$ Moreover, citizens' increased participation in structuring politics at the state level can and should influence the structure of politics at the federal level. As Franita Tolson explains, "[F]ederal officials have to answer to dual constituencies; the idea that the state is not one of these interest groups is a legal fiction, and sometimes the 'people' speak best through their state legislatures." 310 If states could amplify citizens' voices in setting the federal political agenda through how they send their representatives to Washington, rather than simply whom they send, that would itself be a worthy end.

\section{CONCLUSION}

States are as much republics, and at least as competent at republicanism, as is the Union in its current state. A court wrestling with the post-Citizens United era recently held: "It is fundamental to the definition of our national political community that foreign citizens do not have a constitutional right to participate in, and thus may be excluded from, activities of democratic self-government." 311 This suggests an equally fundamental but

came from just 31,385 individuals, a number equal to one ten-thousandth of the U.S. population.").

308. THE FEDERALIST No. 39, at 237 (James Madison) (Clinton Rossiter ed., 1999).

309. Spencer Overton, The Participation Interest, 100 GEO. L. J. 1259, 1273 (2012).

310. Franita Tolson, Partisan Gerrymandering as a Safeguard of Federalism, 2010 UTAH L. REV. 859, 909 (arguing that partisan gerrymandering in state legislatures reinforces federalism by providing a means to influence the composition of their federal congressional delegations).

311. Bluman v. Fed. Election Comm'n., 800 F. Supp. 2d 281, 288 (D.D.C. 2011), aff'd, 132 S. Ct. 1087 (2012); see also Evenwel v. Abbott, No. 14-940 (U.S. Apr. 4, 2016), slip op. at 15 (Thomas, J., concurring in the judgment) ("States are free to serve as 'laboratories' of democracy. That 'laboratory' extends to experimenting about the nature of democracy itself."). 
more modest corollary for our state republics: any state's citizens have a constitutional right to participate in, and thus should be included in, its own activities of democratic self-government. Foremost among those activities is asking what democratic selfgovernment, or republicanism, means. The answer to that question is not likely to come from the federal government anytime soon. It may be worth asking the States. 